\begin{tabular}{l} 
journal homepage: http://ijiemjournal. uns.ac.rs/ \\
International Journal of Industrial \\
Engineering and Management \\
volume $13 /$ No $1 /$ March $2022 / 18-37$ \\
\hline
\end{tabular}

Original research article

\title{
A bi-objective production planning for a flexible supply chain solved using NSGA-II and MOPSO
}

\author{
S. K. Karimia ${ }^{\star}$, S. J. Sadjadia ${ }^{a}$ and S. G. J. Nainia \\ ${ }^{a}$ Department of Industrial Engineering, Iran University of Science and Technology, Tehran, Iran
}

\begin{abstract}
A B STR A C T
Nowadays, rapid changes in customers' demands have redoubled the importance of new concepts such as supply chain flexibility and its application. The extent to which flexibility should be built into supply chains requires full consideration. Flexibility is defined as firms' quick and efficient response to changes. This paper quantifies the positive effects of adding different flexibility dimensions to a production planning bi-objective mathematical model. Four flexibility dimensions are proposed according to the needs of a production plant chosen as the case study. The objective functions are to minimize total costs along with the delivery time of the product, respectively. We also employ two metaheuristic algorithms, NSGA-II and MOPSO, to solve our proposed NP-hard model. Afterwards, we compare both solution strategies based on five criteria to achieve optimal results. Moreover, we compare the performance of both flexible and inflexible models in terms of costs. The results show that applying the flexible model causes a reduction of $\% 22$ in costs.
\end{abstract}

\section{Introduction}

Swafford, et al. [1] define flexibility as the ability to adapt to sudden changes in customers' demands [2]. With the significant development taking place in modern technology and rapid changes in the business environment along with competitiveness, companies have to become highly adaptive in order to have the ability to establish relative supremacy over their rivals. For example, manufacturing plants driven by the high competitive environment show more tendencies towards the concept of having a much greater degree
ARTICLE INFO

Article history:

Received August 7, 2021

Revised November 24, 2021

Accepted December 2, 2021

Published online December 22, 2021

Keywords:

Flexibility;

Supply Chain;

Optimization;

NSGA-II;

MOPSO;

Metaheuristic Methods

${ }^{*}$ Corresponding author:

Sara Khorsandi Karimi

sarakhorsandikarimii@yahoo.com 
Being flexible has different dimensions. Its dimensions have been classified in different ways. Therefore, the importance of SCF as a contributing factor for the survival of companies has been underlined by many researchers; however, it can be rather costly. Consequently, it is highly likely that companies will need to strike a balance between all conflicting ways of reducing costs. Accordingly, having considered the importance of flexible supply chain models, it can be widely perceived as an approach to increasing net profit. Thus, production plants can incorporate flexibility dimensions into their decision-making process, measured at once [5], [6] and [7].

When it comes to an inherent characteristic of the business environment, there is an overriding concern about the uncertainty in manufacturing plants, as it is connected to firm performance and flexibility. It can be considered as companies' goal, and they need to balance these issues, namely cost and flexibility, along with uncertainty [8], [9], [10], and [11].

This study generated a mathematical model to observe the importance of flexibility dimensions and their effects on supply chains. Four suggested flexibility dimensions are: production line, budget, labour team, and sourcing flexibilities under two different scenarios to be compared. To this aim, a bi-objective model is proposed to evaluate supply chain performance. The first objective function is aimed at minimizing the costs in a production plant. The second objective function minimizes the product delivery time (PDT) in the company. To solve the proposed model, we apply and compare two metaheuristic solution methods, NSGA-II and MOPSO, to solve our mathematical model. The model and its results can deepen our understanding of the need for flexibility in our case study as an effective technique to reduce costs. Moreover, we use collected data from a factory that vends automotive parts [1], [12], [13], and [14].

This paper aims at manufacturing companies on a downward path where they find it challenging to be flexible and have flexible production plans. We have also considered uncertain situations during the production process and then defined four flexibility dimensions based on them. Therefore, these dimensions are workable as they have been designed according to reality and can help manufacturing companies overcome the crisis of small profit margins. Moreover, these flexibility dimensions are easy to measure and can be used in quantities problems. Since metaheuristic methods are problem-independent techniques and do not rely on any specificity of the problem, we select to apply them to solve our model. Consequently, they can explore more thor- oughly the solution space and thus provide us with a hopefully better solution. The highlight of our work is as follows: Creating a bio-objective model and solving it using NSGA-II, MOPSO metaheuristic algorithms; Defining different flexibility dimensions for the model; Conducting extensive comparisons over employed methods to find the best solution method; Implementing sensitivity analysis to the best obtained model; Using the data of a real case study of a production plant in Tehran; and Presenting managerial insights for car manufacturing plants and system engineers.

In the remainder of this paper, we have the following sections: Section 2 reviews the available literate on flexible supply chains and metaheuristic methods. Section 3 describes the case study and the problem. In section 4, we present the bi-objective model. In section 5 we explain the solution methods. In Section 6 , we demonstrate the computational results of the study. Finally, in the last section, we draw the conclusions and make recommendations for further research. Moreover, the limitations of the study are mentioned as well.

\section{Literature review}

When studying supply chain management, supply chain flexibility has drawn considerable attention from researchers over the last decade. Moreover, the necessity to study flexibility as a holistic approach and in each firm as a member of the supply chain has been recognized.

Flexibility has been defined in many papers as a critical element in supply chains [6]; as flexibility has different dimensions, it has been defined in various ways. For example, SCF can respond quickly to any unanticipated changes in customers' needs [10] and [12]. Chiu, et al. [5] developed a postponement model for the multi-item replenishment decision featuring commonality, an overtime strategy, and product quality reassurance. As a result, they help manufacturing firms to deal with the competitive and changing markets and keep the high quality of their products while minimizing the total fabrication costs.

Although the need for SCF is clearly underlined in earlier papers, there is still a need for further study in flexibility dimensions. Flexibility dimensions, which are essential by all the supply chain members, are to satisfy the customers' demands effectively [8]. Mendonça Tachizawa and Giménez Thomsen [11] focused on supply flexibility and its different aspects related to the upstream supply chain. The definitions 
so far considered flexibility mainly as the central concept in firms to cope with uncertainties. In a supply chain, SCF can be measured; as a case in point, Gong [15] proposed a flexible supply chain model comprising labour flexibility, information technology, machine flexibility, and routing flexibility. They measured the overall flexibility using economic indicators. The obtained results from this model assisted in deciding beneficial production to produce some products in an uncertain environment. The author showed that some flexibility factors had the most significant effect on the supply chain flexibility, while some did not. Swafford, et al. [1] provided insights into firms sharing characteristics by applying empirical analysis methods to surveying the data from multiple manufacturing companies in the United States. They also presented a performance construction and addressed the impact of supply chain agility and supply chain flexibility on performance. Likewise, Zapp, et al. [16] presented a model that measures the dimensions of strategy, processes, technology, and information technology systems. This was done to develop a supply chain planning system. Similarly, Esmaeilikia, et al. [3] introduced a tactical supply chain planning model with multiple flexibilities, defining flexibility adjustment in contemporary supply chain studies. Chiu, et al. [4] proposed a production planning model in which they derived the optimal production policy for a delayed-differentiation multiproduct system with dual uptime reassuring quality. They also had crucial system performance indicators to help cost-effective decision-making.

In the realm of SCF, most of the optimization models are considered NP-hard problems. In minor cases, exact methods are commonly used by researchers to find the optimal solution. At the same time, when the scale of the problem becomes more extensive, heuristic and metaheuristic approaches are inevitably devised. In this regard, in the literature of flexibility, metaheuristic algorithms have been widely used, in particular, to solve multi-objective models. For example, Panduro, et al. [17] compared different multi-objective optimization methods in their paper. NSGA-II, DEMO, and EM-MOPSO are used in their study and a comparative analysis of the performance between these algorithms. Moreover, Ojstersek, et al. [18] presented the use of evolutionary computation methods for Multi-objective Production Scheduling Optimization, showing the general framework used in evolutionary computation methods. The fundamental division of these methods, individual advantages and limitations are presented in their paper. According to the reviewed literature, we can conclude that research on supply chain flexibility has produced some interesting findings that emphasize that further research is needed. The obtained findings demonstrated that a considerable percentage of supply chain planning review studies mainly highlight the modelling features and solution approach without explicitly discussing the issue of flexibility. Moreover, the focus of studies has been on strategic SCF, mainly in non-mathematical modelling (e.g. empirical-oriented work. We develop a bi-objective model, a production planning model, to improve supply chain performance. The first objective function expresses the total production cost over time, whereas the second objective aims to minimize the product delivery time (PDT). We have summarized the studies whose focus was on supply chain flexibility in Table 1.

Table 1 shows the studies focusing on supply chain flexibility. Nearly one-third of these studies are only theatrical models. Among the rest, about 20 percent have mathematical models. They mainly analyze the need for flexibility dimensions. However, there is no measurement method to measure them under uncertainty. Besides, what we can focus on, are the solutions methods used to solve the models. These papers used heuristic methods to solve the problem, which differs from our paper in which we applied meta-heuristic methods and compared them according to different criteria. We also compared the flexibility dimensions to find out the best ones for this model. We add four flexibility dimensions to the basic inflexible model as follows: (1) Production line flexibility: the company's ability to have some production lines in a company and activate them whenever needed, (2) Budget flexibility: the company's ability to put more capital into the production process to get a high rate of return on the capital, (3) Sourcing flexibility: the company's ability to work with not only one supplier for components or raw materials, and (4) Labor team flexibility: the company's ability to train different labor teams and to use them whenever needed.

We apply NSGA-II and MOPSO metaheuristic algorithms to solve our mathematical model. As mentioned in previous studies, these two algorithms are suitable for solving multi-objective optimization problems, especially the ones with two objective functions (2017). Furthermore, the two algorithms are compared in terms of five criteria. We were motivated by an automotive parts factory in Iran. Therefore, this study caters for companies in search of better performance in the area of SCF. In a nutshell, the results show the improvement in supply chain performance by a $22 \%$ reduction in costs. 
Table 1. A summary of studies on supply chain flexibility

\begin{tabular}{|c|c|c|c|c|c|c|c|c|c|}
\hline Number & $\begin{array}{l}\text { Authors' } \\
\text { names }\end{array}$ & Year & $\begin{array}{c}\text { The Main Focus of The } \\
\text { Paper }\end{array}$ & $\begin{array}{l}\text { Type Of } \\
\text { study }\end{array}$ & Model type & $\begin{array}{l}\text { Flexibility } \\
\text { dimensions }\end{array}$ & $\begin{array}{l}\text { Solution } \\
\text { method } \\
\text { /approach }\end{array}$ & $\begin{array}{c}\text { Type of } \\
\text { uncertainty }\end{array}$ & $\begin{array}{l}\text { Performance } \\
\text { measurement }\end{array}$ \\
\hline 1. & $\begin{array}{l}\text { Das and } \\
\text { Abdel-Malek } \\
{[12]}\end{array}$ & 2003 & $\begin{array}{l}\text { A measure for estimating SCF } \\
\text { as a function of varying order } \\
\text { quantities \& supply lead times. }\end{array}$ & Theoretical & - & A general view & - & product & - \\
\hline 2. & $\begin{array}{l}\text { Duclos, et al. } \\
{[8]}\end{array}$ & 2003 & $\begin{array}{l}\text { An integrated conceptual } \\
\text { model for SCF. }\end{array}$ & Theoretical & - & $\begin{array}{l}\text { Logistics, supply, } \\
\text { organizational, } \\
\text { information system, } \\
\text { market }\end{array}$ & - & - & - \\
\hline 3. & $\begin{array}{l}\text { Chiang and } \\
\text { Monahan } \\
\text { [18] }\end{array}$ & 2005 & $\begin{array}{l}\text { A } 2 \text { echelon dual channel } \\
\text { inventory model. }\end{array}$ & Theoretical & $\begin{array}{l}\text { Two-echelon } \\
\text { dual-channel } \\
\text { inventory } \\
\text { model }\end{array}$ & - & $\begin{array}{l}\text { statistical } \\
\text { anlysis }\end{array}$ & - & $\begin{array}{l}\text { performance } \\
\text { of two } \\
\text { other possible } \\
\text { channel } \\
\text { distribution } \\
\text { strategies }\end{array}$ \\
\hline 4. & $\begin{array}{l}\text { Archer, et al. } \\
\text { [27] }\end{array}$ & 2006 & $\begin{array}{l}\text { A conceptual framework for } \\
\text { implementing and managing } \\
\text { SCF in SC organizations (a } 3 \\
\text {-stage approach) }\end{array}$ & Theoretical & - & - & - & - & $\begin{array}{l}\text { cost, time, } \\
\text { quality }\end{array}$ \\
\hline 5. & $\begin{array}{l}\text { Wu, et al. } \\
{[28]}\end{array}$ & 2006 & $\begin{array}{l}\text { Measures for risk reduction ... } \\
\text { considering SCF }\end{array}$ & Theoretical & - & A general view & - & demand & - \\
\hline 6. & $\begin{array}{l}\text { Stevenson and } \\
\text { Spring [29] }\end{array}$ & 2007 & $\begin{array}{l}\text { A timely review of the available } \\
\text { literature on SCF }\end{array}$ & Theoretical & & Only definitions & - & - & $\begin{array}{l}\text { Relationship } \\
\text { between } \\
\text { flexibility and } \\
\text { performance }\end{array}$ \\
\hline 7. & $\begin{array}{l}\text { Gunasekaran, } \\
\text { et al. [30] }\end{array}$ & 2007 & $\begin{array}{l}\text { Synthesize the existing } \\
\text { contributions to manufacturing } \\
\text { and SCF. }\end{array}$ & Theoretical & $\begin{array}{l}\text { Conceptual } \\
\text { model }\end{array}$ & $\begin{array}{l}\text { Conceptual } \\
\text { framework }\end{array}$ & - & demand & \\
\hline 8. & Gong [15] & 2008 & $\begin{array}{l}\text { A SCF model, measured by an } \\
\text { economic index. }\end{array}$ & Theoretical & $\begin{array}{l}\text { Linear } \\
\text { programming }\end{array}$ & $\begin{array}{l}\text { Labar, } \\
\text { transportation, } \\
\text { machines }\end{array}$ & $\begin{array}{l}\text { Exact } \\
\text { methods } \\
\text { MATLAB }\end{array}$ & - & $\begin{array}{l}\text { Entire supply } \\
\text { chain }\end{array}$ \\
\hline 9. & $\begin{array}{l}\text { Kumar, et al. } \\
\text { [31] }\end{array}$ & 2008 & $\begin{array}{l}\text { Identify \& evaluate the } \\
\text { relationship the flexibility } \\
\text { enablers. }\end{array}$ & Theoretical & $\begin{array}{l}\text { Conceptual } \\
\text { model }\end{array}$ & $\begin{array}{l}\text { Product, supply, } \\
\text { response to } \\
\text { customers' needs }\end{array}$ & - & - & - \\
\hline 10. & $\begin{array}{l}\text { Chandra and } \\
\text { Grabis [13] }\end{array}$ & 2009 & $\begin{array}{l}\text { Research on the problem of } \\
\text { planning \& operating flexible } \\
\text { SC s under uncertainty. }\end{array}$ & Theoretical & - & - & - & $\begin{array}{l}\text { Demand } \\
\text { and supply }\end{array}$ & - \\
\hline 11. & $\begin{array}{l}\text { Chandra and } \\
\text { Grabis [13] }\end{array}$ & 2010 & $\begin{array}{l}\text { A model to select the supplier } \\
\text { based on SCF }\end{array}$ & Theoretical & $\begin{array}{l}\text { Conceptual } \\
\text { model }\end{array}$ & - & - & $\begin{array}{l}\text { Number of } \\
\text { products }\end{array}$ & - \\
\hline 12. & $\begin{array}{l}\text { Zapp, et al. } \\
\text { [16] }\end{array}$ & 2012 & $\begin{array}{l}\text { A reference model which } \\
\text { outlines measures for the } \\
\text { dimensions of strategy, } \\
\text { processes, IT systems \& ... }\end{array}$ & Theoretical & $\begin{array}{l}\text { Conceptual } \\
\text { model }\end{array}$ & - & $\begin{array}{l}\text { Collaborative } \\
\text { Planning } \\
\text { Forecasting } \\
\text { approach }\end{array}$ & - & - \\
\hline 13. & $\begin{array}{l}\text { Jenkins and } \\
\text { Wright [32] }\end{array}$ & 1998 & $\begin{array}{l}\text { Use of DSS to manage an } \\
\text { inflexible SC(U.K retailor of } \\
\text { petroleum) }\end{array}$ & Empirical & - & $\begin{array}{l}\text { Definitions of } \\
\text { flexibility }\end{array}$ & - & - & - \\
\hline 14. & $\begin{array}{l}\text { Mendonça } \\
\text { Tachizawa } \\
\text { and Giménez } \\
\text { Thomsen [11] }\end{array}$ & 2007 & $\begin{array}{l}\text { Focus on SCF, its aspects } \\
\text { related to the upstream SC }\end{array}$ & Empirical & - & Supply, sourcing & - & $\begin{array}{l}\text { Volume, } \\
\text { distribution }\end{array}$ & $\begin{array}{l}\text { Quality, cost, } \\
\text { price }\end{array}$ \\
\hline 15. & $\begin{array}{l}\text { Coronado M } \\
\text { and Lyons [33] }\end{array}$ & 2007 & $\begin{array}{l}\text { Evaluate the implications } \\
\text { of operations flexibility in } \\
\text { industrial SC }\end{array}$ & Empirical & $\begin{array}{l}\text { Conceptual } \\
\text { model }\end{array}$ & - & $\begin{array}{l}\text { Value Stream } \\
\text { Mapping }\end{array}$ & $\begin{array}{l}\text { Logistic, } \\
\text { distribution }\end{array}$ & $\begin{array}{l}\text { Balanced score } \\
\text { card }\end{array}$ \\
\hline 16. & $\begin{array}{l}\text { Merschmann } \\
\text { and } \\
\text { Thonemann } \\
{[14]}\end{array}$ & 2011 & $\begin{array}{l}\text { Address the relationship } \\
\text { between environmental } \\
\text { uncertainty \& SCF \& firm } \\
\text { performance }\end{array}$ & Empirical & $\begin{array}{l}\text { Mathematical } \\
\text { model }\end{array}$ & $\begin{array}{l}\text { Production } \\
\text { time, product } \\
\text { development, new } \\
\text { product, order } \\
\text { level, Ability to } \\
\text { distribute, customer } \\
\text { service, Distribution } \\
\text { reliability, response } \\
\text { to market changes }\end{array}$ & $\begin{array}{l}\text { Partial least } \\
\text { square }\end{array}$ & $\begin{array}{l}\text { Number of } \\
\text { suppliers, } \\
\text { quality, } \\
\text { number of } \\
\text { products }\end{array}$ & $\begin{array}{l}\text { Returns and } \\
\text { sales growth. }\end{array}$ \\
\hline
\end{tabular}




\begin{tabular}{|c|c|c|c|c|c|c|c|c|c|}
\hline 17. & Yi, et al. [34] & 2011 & $\begin{array}{l}\text { Illustrate \& examine the } \\
\text { different flexibility strategies } \\
\text { adopted by SC participants }\end{array}$ & Empirical & $\begin{array}{l}\text { A qualitative } \\
\text { model to } \\
\text { examine the } \\
\text { relationship } \\
\text { between } \\
\text { flexibility and } \\
\text { uncertainty }\end{array}$ & $\begin{array}{l}\text { Source, Operating } \\
\text { systems, } \\
\text { Organizational } \\
\text { system, distribution }\end{array}$ & - & $\begin{array}{l}\text { Supply, } \\
\text { demand, } \\
\text { competition }\end{array}$ & - \\
\hline 18. & $\begin{array}{l}\text { Malik and } \\
\text { Sarkar [35] }\end{array}$ & 2020 & $\begin{array}{l}\text { model with a manageable lead } \\
\text { time for the Stackelberg game } \\
\text { policy and centralized decision } \\
\text { policy }\end{array}$ & Empirical & $\begin{array}{l}\text { Mathematical } \\
\text { model }\end{array}$ & $\begin{array}{l}\text { flexible production } \\
\text { system }\end{array}$ & $\begin{array}{l}\text { Analytical } \\
\text { methodology } \\
\text { and solution }\end{array}$ & Demand & - \\
\hline 19. & $\begin{array}{l}\text { Delic and Eyers } \\
\text { [36] }\end{array}$ & 2020 & $\begin{array}{l}\text { conceptual framework for } \\
\text { analyzing the relationships } \\
\text { among Additive Manufacturing } \\
\text { adoption, flexibility, and } \\
\text { performance in the supply } \\
\text { chain context }\end{array}$ & $\begin{array}{l}\text { Conceptual } \\
\text { framework }\end{array}$ & $\begin{array}{l}\text { Quantitative } \\
\text { approach }\end{array}$ & $\begin{array}{l}\text { Supply chain } \\
\text { flexibility in general }\end{array}$ & $\begin{array}{l}\text { questionnaire } \\
\text { survey }\end{array}$ & - & $\begin{array}{l}\text { Supply chain } \\
\text { performance }\end{array}$ \\
\hline 20. & $\begin{array}{l}\text { Singh, et al. } \\
\text { [19] }\end{array}$ & 2020 & $\begin{array}{l}\text { extracted } 11 \text { supply chain } \\
\text { flexibility dimensions } \\
\text { through extensive literature } \\
\text { review. The authors used a } \\
\text { decision-making evaluation } \\
\text { laboratory } \\
\text { (DEMATEL) to make causal } \\
\text { analysis and prioritizing the } \\
\text { dimensions }\end{array}$ & Empirical & $\begin{array}{l}\text { Mathematical } \\
\text { model }\end{array}$ & $\begin{array}{l}11 \text { different flexibility } \\
\text { dimensions }\end{array}$ & $\begin{array}{l}\text { DEMATEL } \\
\text { analysis }\end{array}$ & Demand & - \\
\hline 21. & $\begin{array}{l}\text { Martínez } \\
\text { Sánchez and } \\
\text { Pérez Pérez } \\
\text { [37] }\end{array}$ & 2005 & $\begin{array}{l}\text { Explore the relationship } \\
\text { between the dimensions of SCF } \\
\text { \& firm performance }\end{array}$ & $\begin{array}{l}\text { Theoretical- } \\
\text { Empirical }\end{array}$ & $\begin{array}{l}\text { A qualitative } \\
\text { model to } \\
\text { examine the } \\
\text { relationship } \\
\text { between } \\
\text { flexibility and } \\
\text { uncertainty } \\
\text { and efficiency }\end{array}$ & $\begin{array}{l}\text { distribution, volume, } \\
\text { Route, product, } \\
\text { access, } \\
\text { Market response, } \\
\text { shipping, } \\
\text { Innovation, } \\
\text { Source }\end{array}$ & $\begin{array}{l}\text { Seven Point } \\
\text { Likert }\end{array}$ & - & - \\
\hline 22. & $\begin{array}{l}\text { Choy, et al. } \\
\text { [38] }\end{array}$ & 2008 & $\begin{array}{l}\text { An intelligent measurement } \\
\text { system for performance in SC }\end{array}$ & $\begin{array}{l}\text { Theoretical- } \\
\text { Empirical }\end{array}$ & $\begin{array}{l}\text { Qualitative } \\
\text { model for } \\
\text { measuring } \\
\text { performance }\end{array}$ & Logistic systems & $\begin{array}{l}\text { Knowledge } \\
\text {-based } \\
\text { Logistics } \\
\text { Performance } \\
\text { Measurement } \\
\text { System }\end{array}$ & - & $\begin{array}{l}\text { Designs } \\
\text { intelligent } \\
\text { systems to } \\
\text { measure } \\
\text { performance. }\end{array}$ \\
\hline 23. & $\begin{array}{l}\text { Swafford, et } \\
\text { al. [1] }\end{array}$ & 2008 & $\begin{array}{l}\text { Impact of SC agility \& SCF on } \\
\text { performance }\end{array}$ & $\begin{array}{l}\text { Theoretical- } \\
\text { Empirical }\end{array}$ & $\begin{array}{l}\text { Qualitative } \\
\text { model }\end{array}$ & - & SEM & - & $\begin{array}{l}\text { Examines the } \\
\text { relationship } \\
\text { between } \\
\text { flexibility and } \\
\text { performance } \\
\text { with a statistical } \\
\text { hypothesis test. }\end{array}$ \\
\hline 24. & $\begin{array}{l}\text { Acur, et al. } \\
\text { [39] }\end{array}$ & 2009 & An empirical study of SCF & $\begin{array}{l}\text { Theoretical- } \\
\text { Empirical }\end{array}$ & $\begin{array}{l}\text { Qualitative } \\
\text { model }\end{array}$ & $\begin{array}{l}\text { Settings, Planning } \\
\text { and control }\end{array}$ & $\begin{array}{l}\text { Research } \\
\text { questions. }\end{array}$ & - & - \\
\hline 25. & Hua, et al. [40] & 2009 & $\begin{array}{l}\text { The area of achieving } \\
\text { competitiveness through SCF }\end{array}$ & $\begin{array}{l}\text { Theoretical- } \\
\text { Empirical }\end{array}$ & - & - & - & - & - \\
\hline 26. & $\begin{array}{l}\text { Gosling, et al. } \\
\text { [41] }\end{array}$ & 2010 & $\begin{array}{l}\text { Examine how buying } \\
\text { organizations can configure } \\
\text { their supply networks to } \\
\text { achieve SCF }\end{array}$ & $\begin{array}{l}\text { Theoretical- } \\
\text { Empirical }\end{array}$ & - & Seller and source & - & - & - \\
\hline 27. & Chuu [42] & 2011 & A framework for evaluating SCF & $\begin{array}{l}\text { Theoretical- } \\
\text { Empirical }\end{array}$ & $\begin{array}{l}\text { Qualitative } \\
\text { model }\end{array}$ & $\begin{array}{l}\text { Network, supply, } \\
\text { operating } \\
\text { systems, logistics, } \\
\text { operational } \\
\text { systems }\end{array}$ & $\begin{array}{l}\text { Modified } \\
\text { linguistic } \\
\text { ordered } \\
\text { weighted } \\
\text { geometric } \\
\text { averaging } \\
\text { operator, } \\
\text { fuzzy systems }\end{array}$ & Demand & $\begin{array}{l}\text { Estimates } \\
\text { efficiency or } \\
\text { cost with a } \\
\text { verbal fuzzy } \\
\text { approach. }\end{array}$ \\
\hline 28. & $\begin{array}{l}\text { Koçoğlu, et } \\
\text { al. [43] }\end{array}$ & 2011 & $\begin{array}{l}\text { Evince the influence of SC } \\
\text { integration on info. Sharing } \\
\text { \& SCP }\end{array}$ & $\begin{array}{l}\text { Theoretical- } \\
\text { Empirical }\end{array}$ & $\begin{array}{l}\text { Conceptual } \\
\text { model }\end{array}$ & - & $\begin{array}{l}\text { Statistical } \\
\text { methods }\end{array}$ & - & $\begin{array}{l}\text { Cost, inventory } \\
\text { usage, supply } \\
\text { chain reliability, } \\
\text { responsiveness } \\
\text { and flexibility } \\
\text { are considered } \\
\text { performance } \\
\text { indicators. }\end{array}$ \\
\hline
\end{tabular}


A multifaceted scale for

29.

Moon, et al. [2]

2012

scF through an empirical investigation
Theoretical- Qualitative Empirical model
Operating

systems, source, Partial Least

Distribution Square

information

$\begin{array}{ll}\text { systems } & \text { Equation } \\ & \text { Modeling }\end{array}$
Examines the relationship between flexibility and performance by hypothesis testing.
The relationship between the manufacturer's management on

31. Chang and
Huang [44] 2012 how to align their suppliers for delivery flexibility to respond quickly to customer demand
Theoretical- Theoretical Empirical framework

Theoretical- Mathematical Empirical model
Supplier, logistics,

change, new

product
Statistical methods
Supply

supplier delivery

flexibility/revere logistic

\section{nove}

neighborhood

rough set

theory

approach
Statistical

methods

\section{Material and method}

\subsection{Problem description}

In previous studies, supply chain flexibility has been adequately defined, as mentioned in the previous section. While reading the former papers, the question arises as to whether or not all flexibility dimensions can be built into a system. It is imperative that we identify to what extent flexibility dimensions can be incorporated into production planning, as being flexible can cause a rise in a company's costs. When it comes to meeting the customers' needs, companies need to deal with uncertain situations to compete with their rivals. To address this problem, we propose two flexible and inflexible mathematical models to compare and find the more acceptable one in terms of costs. As described in previous studies [1], [3], the need for flexibility in enterprises based on different internal and external factors that act as drivers of flexibility still exists.

This paper formulates a supply chain composed of four different levels: warehouses, end-users, suppliers, and production plants which are shown schematically in Figure 1. The needs of end-users are estimated for each product.

Providing a range of products to the two leading after-markets and local auto manufacturers, Forgekar is an Iranian automotive parts manufacturer located in Qazvin (150 km northwest of Tehran, where end-

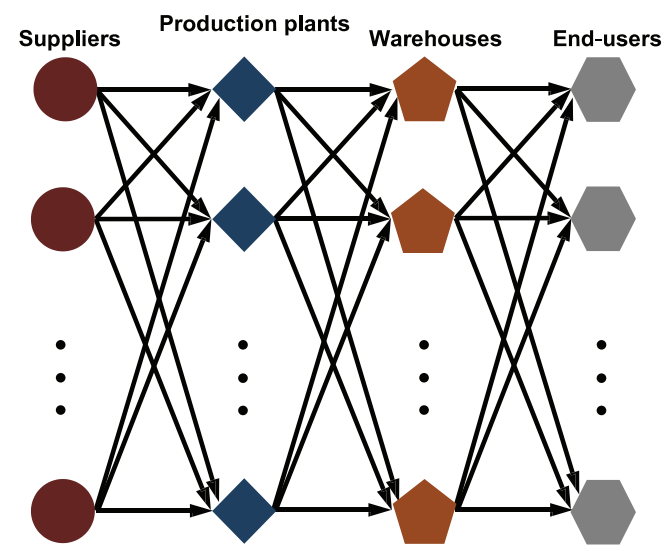

Figure 1. Schematic diagram of the proposed supply chain model

users plant base) and produces seat runners for family cars primarily. With competition from cheap imports, Iran's car industry currently is facing an acute financial crisis. Nonetheless, the company displays an absolute commitment to meet all demands of its two main end-users. Labors work in two different periods are overtime shifts and regular time. There are three production plants established in the factory premises, where two top products are produced. These plants and two warehouses function separately. There are several machine types in the production plants, but we classify them into two groups based on the process done on each item. Then, three different suppliers provide raw materials for production plants. As it has been found in our reports from visits, the company might face some challenges such as shortage of raw 
material, labors absentees, fires outbreak, power cut and machines cut out, and needs to make detailed plans to avoid decreasing its turnover during any crisis. Delivery time is also one of the company's primary concerns because an agreement has been reached between the manufacturer and the end-users that if the product is not delivered on time, the company should risk incurring financial penalties. To deal with these unexpected challenges, companies need to add flexibility dimensions to supply chain modelling. The data was obtained by administering questionnaires that the financial manager and other employees completed. Based on the built-up database, we compare and analyze two different scenarios to determine the proper one for our examination. The outcomes are presented in the next section.

\subsection{Notations}

The notation of decision variables, indices, and parameters is presented below (Table 2-4).

Table 2. Indices used in the study

\begin{tabular}{ll}
\hline I & Set of product type \\
P & Set of the production plant \\
C & Set of component type \\
T & Set of time period \\
E & Set of end-user \\
S & Set of supplier \\
L & Set of the labor team \\
M & Set of machine type \\
W & Set of warehouse \\
\hline
\end{tabular}

$U C_{c s p t}=\{1$,If component $c$ is bought from supplier $s$ for plant $p i$ in period $t$, If component $c$ is not bought from supplier $s$ for plant $p i$ in period $t$

$V_{\text {ipet }}=\{1$, If product $i$ is transported from plant $p$ to end user e in period t 0 ,If product $i$ is not transported from plant $p$ to end user e in period $t$

$V_{i p w t}^{\prime}=\{1$, If product $i$ is transported from plant $p$ to warehouse $w$ in period $t 0$,If product $i$ is not transported from plant $p$ to warehouse $w$ in period $t$

$V_{\text {iwet }}^{\prime \prime}=\{1$, If product $\mathrm{i}$ is transported warehouse $\mathrm{w}$ to end user e in period $t 0$,If product $i$ is not transported warehouse $w$ to enduser e in period $t$

$G_{c s p t}=\{1$, If plant $p$ is open and produces product $i$ in period $t 0$,If plant $p$ is not open in period $t$

\subsection{Bi-Objective supply chain flexibility model}

A bi-objective flexibility model is developed to integrate production line flexibility, budget flexibility, labor team flexibility, and sourcing flexibility. Furthermore, the proposed flexibility model can assist the company in providing profoundly flexible decisions. Our study has produced a mathematical model based on the models of Gong [15] and Esmaeilikia et al. [11].

The two constraints and objective functions are presented as below:

$f_{1}=\operatorname{Min} \sum_{\mathrm{p}} \sum_{t} \mathrm{f}_{\mathrm{pt}} \cdot \mathrm{G}_{\mathrm{pt}}+\sum_{\mathrm{i}} \sum_{\mathrm{p}} \sum_{t} \mathrm{a}_{\text {iplt }} \cdot \mathrm{A}_{\text {iplt }}+\sum_{\mathrm{i}} \sum_{\mathrm{p}} \sum_{l} \sum_{t} \mathrm{a}_{\text {iplt }}^{\prime} \cdot \mathrm{A}_{\mathrm{iplt}}^{\prime}+$ $\sum_{\mathrm{i}} \sum_{\mathrm{p}} \sum_{t} \mathrm{r}_{\mathrm{ipt}} \cdot \mathrm{R}_{\mathrm{ipt}}+\sum_{\mathrm{i}} \sum_{\mathrm{p}} \sum_{t} \mathrm{~h}_{\mathrm{ipt}}^{\prime} \cdot \mathrm{X}_{\mathrm{ipt}}^{\prime}+\sum_{\mathrm{c}} \sum_{\mathrm{p}} \sum_{t} \mathrm{~h}_{\mathrm{cpt}} \cdot \mathrm{x}_{\mathrm{cpt}}+$ $\sum_{\mathrm{i}} \sum_{\mathrm{p}} \sum_{\mathrm{e}} \sum_{t} \mathcal{T}_{\text {ipet }} \cdot \mathrm{J}_{\text {ipet }}+\sum_{\mathrm{i}} \sum_{\mathrm{w}} \sum_{\mathrm{e}} \sum_{t} \mathcal{T}_{\text {iwet }}^{\prime \prime} \cdot \mathrm{J}_{\text {ipet }}^{\prime \prime}+$

$\sum_{\mathrm{i}} \sum_{\mathrm{p}} \sum_{\mathrm{l}} \sum_{t} \mathrm{WA}_{\text {iplt }} \cdot \mathrm{A}_{\text {iplt }} \cdot \beta_{\text {iplt }}+\sum_{\mathrm{i}} \sum_{\mathrm{p}} \sum_{\mathrm{l}} \sum_{t} \mathrm{WA}_{\text {iplt }}^{\prime} \cdot \mathrm{A}_{\text {iplt }}^{\prime} \cdot \beta_{\text {iplt }}+$ $\sum_{\mathrm{i}} \sum_{\mathrm{p}} \sum_{t} \mathrm{~b}_{\mathrm{ipt}} \cdot \mathrm{B}_{\mathrm{ipt}}+\sum_{\mathrm{i}} \sum_{\mathrm{p}} \sum_{t} \mathrm{Y}_{\mathrm{iwt}} \cdot \mathrm{K}_{\mathrm{iwt}}$

$$
\begin{aligned}
f_{2}=\min \sum_{\mathrm{i}} & \sum_{\mathrm{p}} \sum_{l} \sum_{t} \mathrm{~A}_{\mathrm{iplt}} \cdot \beta_{\mathrm{iplt}}+\sum_{\mathrm{i}} \sum_{\mathrm{w}} \sum_{e} \sum_{t} \mathrm{tt}^{\prime}{ }_{\mathrm{iwet}} \cdot \mathrm{V}^{\prime}{ }_{\text {iwet }} \\
& +\sum_{\mathrm{i}} \sum_{\mathrm{p}} \sum_{e} \sum_{t} \mathrm{tt}^{\prime \prime}{ }_{\text {ipet }} \cdot \mathrm{V}^{\mathrm{N}}{ }_{\text {ipet }}
\end{aligned}
$$

Equations (1) and (2) show the two objective functions, in which the first one aims to lower the total cost of the supply chain, and the second one lowers the delivery time.

Subject to:

$X_{\text {cpt }}=\sum_{s} Q_{\text {cspt }}-\left(A_{\text {iplt }}+A_{\text {iplt }}^{\prime}\right) \cdot$ no $_{\text {ci }}$

$\forall \mathrm{i}, \mathrm{p}, \mathrm{t}, \mathrm{l}, \mathrm{c}$

$X_{\text {ipt }}^{\prime}=\left(A_{\text {iplt }}+A_{\text {iplt }}^{\prime}\right)-\left[\sum_{w} J_{\text {ipwt }}^{\prime}+\sum_{\mathrm{e}} J_{\text {ipet }}\right]$

$\forall \mathrm{i}, \mathrm{p}, \mathrm{t}, \mathrm{l}$

$\mathrm{Y}_{\mathrm{iwt}}=\sum_{\mathrm{w}} \mathrm{J}_{\text {ipwt }}^{\prime}-\sum_{\mathrm{e}} \mathrm{J}_{\text {iwet }}^{\prime \prime}$

$\forall \mathrm{i}, \mathrm{w}, \mathrm{t}$

Equations (3) and (4) and (5) demonstrate material balance constraint in the process of production, which means the number of components held in plants equals the total number of components purchased from suppliers for plants subtracted from the number of components used to make products in each period. Also, the number of products held in plants equals the total number of products made by labor teams in plants in regular time and overtime 
Table 3. Parameters involved in the study

\begin{tabular}{|c|c|}
\hline$p c_{c s p t}$ & Purchase cost of a unit of component $\mathrm{c}$ for plant $\mathrm{p}$ from supplier $\mathrm{s}$ in time $\mathrm{t}$ \\
\hline$d_{i e t}$ & Product i demand by end-user e in time $t$ \\
\hline$f_{p t}$ & Fixed costs of plant $p$ in period $t$ \\
\hline$a_{\text {ipt }}$ & The overhead production cost of a unit of product $i$ in regular time in plant $p$ in time $t$ \\
\hline$T_{i p w t}^{\prime}$ & Transportation cost of a unit of product $\mathrm{i}$ to warehouse $\mathrm{w}$ from plant $\mathrm{p}$ in time $\mathrm{t}$ \\
\hline$r_{i p t}$ & Purchase cost of a unit of product $\mathrm{i}$ in plant $\mathrm{p}$ in time $\mathrm{t}$ \\
\hline$h_{c p t}$ & Cost of holding a unit of component $\mathrm{c}$ in plant $\mathrm{p}$ in time $\mathrm{t}$ \\
\hline$T_{\text {ipet }}$ & Transportation cost of a unit of product $i$ to end-user e from plant $p$ in time $t$ \\
\hline$b_{\text {ipt }}$ & Lost sales cost of a unit of product $\mathrm{i}$ in plant $\mathrm{p}$ in time $\mathrm{t}$ \\
\hline$b_{i p t}^{\prime}$ & Most number of lost sales of product $i$ in plant $p$ in time $t$ \\
\hline$n o_{c i}$ & Units number of component utilized to produce one unit of time i \\
\hline$w_{c p t}$ & Ultimate capacity of plant $\mathrm{p}$ to have a unit of component $\mathrm{c}$ in time $\mathrm{t}$ \\
\hline$w_{i p t}^{\prime}$ & Ultimate capacity of plant $p$ to have a unit of product $\mathrm{i}$ in time $\mathrm{t}$ \\
\hline$u_{i p t}$ & Ultimate production capacity of product $\mathrm{i}$ in plant $\mathrm{p}$ in regular time in time $\mathrm{t}$ \\
\hline$u_{i p t}^{\prime}$ & Ultimate production capacity of product i in plant $\mathrm{p}$ in overtime in time $t$ \\
\hline$u_{i p t}^{\prime \prime}$ & The product i maximum number that can be outsourced for plant $\mathrm{p}$ in time $\mathrm{t}$ \\
\hline$h_{i p t}^{\prime}$ & Cost of holding one unit of product $i$ in plant $p$ in time $t$ \\
\hline$p q_{c s p t}^{\min }$ & Least number of component $\mathrm{c}$ bought for plant $\mathrm{p}$ from supplier $\mathrm{s}$ in time $\mathrm{t}$ \\
\hline$p q_{c s p t}^{\max }$ & Ultimate capacity of the supplier $\mathrm{s}$ to sell component $\mathrm{c}$ to plant $\mathrm{p}$ in time $\mathrm{t}$ \\
\hline$\varepsilon_{s t}^{\min }$ & Least number of the component can be bought from supplier s in time t \\
\hline$a_{i p t}^{\prime}$ & The cost of overhead production of a unit of product $i$ in plant $p$ in overtime in time $t$ \\
\hline$t q^{\prime \max }{ }_{\text {iwet }}^{\max }$ & Ultimate number of product i sent to end-user e from warehouse $w$ in time t \\
\hline$t q^{\prime \prime \min t}$ & Ultimate number of product i sent to warehouse $w$ from plant $p$ in time $t$ \\
\hline$t q_{i p w t}$ & Ultimate number of product i sent to warehouse $w$ from plant $p$ in time $t$ \\
\hline$\varepsilon_{t}^{\prime \min }$ & Least number of transportation in time $t$ \\
\hline$k_{i w t}$ & Cost of holding a unit of product $i$ in warehouse $w$ in time $t$ \\
\hline$k_{i w t}^{\prime}$ & Ultimate capacity of warehouse $w$ for product $\mathrm{i}$ in time $\mathrm{t}$ \\
\hline$t t_{\text {ipet }}$ & Necessary time to convey a unit of $t$ product $i$ to end-user e from plant $p$ in time $t$ \\
\hline$t t_{\text {iwet }}$ & Transport time of a unit of product $i$ to end-user e from warehouse $w$ in time $t$ \\
\hline$w a_{i p l t}$ & The labour team I wage for creating a unit of product $\mathrm{i}$ in regular time in plant $\mathrm{p}$ in time $\mathrm{t}$ \\
\hline$w a_{i p l t}^{\prime}$ & The labour team I wage for creating a unit of product $\mathrm{i}$ in overtime in plant $\mathrm{p}$ in period $\mathrm{t}$ \\
\hline$n l_{p t}$ & labour team I number in plant $\mathrm{p}$ in time $\mathrm{t}$ \\
\hline$n m_{p t}$ & Number of machines $m$ in plant $p$ in time $t$ \\
\hline$n c_{c m t}$ & Number of component c generated in machine $\mathrm{m}$ in time $\mathrm{t}$ \\
\hline$\beta_{\text {iplt }}$ & The necessary time to create a unit of product $\mathrm{i}$ in plant $\mathrm{p}$ by labour team I in time $\mathrm{t}$ \\
\hline$\delta_{m t}$ & The machine $\mathrm{m}$ probability of working correctly in time $\mathrm{t}$ \\
\hline$t m_{p m t}$ & Total working time of machine $\mathrm{m}$ in plant $\mathrm{p}$ in time $\mathrm{t}$ \\
\hline$t l_{p l t}$ & The labour I Total working time in plant $p$ in regular time in time $t$ \\
\hline$t l_{p l t}^{\prime}$ & The labour I Total working time in plant $p$ in overtime in time $t$ \\
\hline$t c_{c p m t}$ & The necessary time to process a unit of component $\mathrm{c}$ by machine $\mathrm{m}$ in plant $\mathrm{p}$ in time $\mathrm{t}$ \\
\hline$s_{c m t}$ & Machine m Set-up time \\
\hline$\alpha_{i p m l t}$ & Ultimate capacity of production time of product $\mathrm{i}$ on machine $\mathrm{m}$ in regular time in plant $\mathrm{p}$ by labour $\mathrm{I}$ in time $\mathrm{t}$ \\
\hline$\alpha_{i p m l t}^{\prime}$ & Ultimate capacity of production time of product $\mathrm{i}$ on machine $\mathrm{m}$ in overtime in plant $\mathrm{p}$ by labour $\mathrm{I}$ in time $\mathrm{t}$ \\
\hline
\end{tabular}


Table 4. Decision variables used in the study

\begin{tabular}{ll}
\hline$J_{i p w t}^{\prime}$ & The product i number sent to warehouse $\mathrm{w}$ from plant $\mathrm{p}$ in time $\mathrm{t}$ \\
$Q_{C S P t}$ & The component c purchased number for plant $\mathrm{p}$ from supplier $\mathrm{s}$ in time $\mathrm{t}$ \\
$B_{\text {ipt }}$ & The product i number backordered in plant $\mathrm{p}$ in time $\mathrm{t}$ \\
$A_{\text {iplt }}^{\prime}$ & The product i made number by labour team I in overtime in plant $\mathrm{p}$ in period $\mathrm{t}$ in time $\mathrm{t}$ \\
$R_{\text {ipt }}$ & The product i outsourced number by plant $\mathrm{p}$ in time $\mathrm{t}$ \\
$X_{\text {cpt }}$ & The component c number held in plant $\mathrm{p}$ in time $\mathrm{t}$ \\
$X_{\text {ipt }}^{\prime}$ & The product i number held in plant $\mathrm{p}$ i in time $\mathrm{t}$ \\
$J_{\text {ipet }}$ & The product i number sent from plant $\mathrm{p}$ to end user e in time $\mathrm{t}$ \\
$J_{\text {iwet }}^{\prime \prime}$ & The product i number sent to end user e from warehouse $\mathrm{w}$ in time $\mathrm{t}$ \\
$Y_{\text {iwt }}$ & The product i number held in warehouse $\mathrm{w}$ in time $\mathrm{t}$ \\
$A_{\text {iplt }}$ & The product i created number of by labour team I in regular time in plant $\mathrm{p}$ in time $\mathrm{t}$ in period $\mathrm{t}$ \\
\hline
\end{tabular}

subtracted from the number of products transported from the plants to either warehouses or end-users in each period. Equation (5) denotes that warehouses balance constraint.

$$
\begin{gathered}
\sum_{\mathbf{p}} \sum_{\mathrm{l}} \sum_{\mathrm{t}}\left(\mathrm{A}_{\mathrm{iplt}}+\mathrm{A}_{\mathrm{iplt}}^{\prime}\right)+\sum_{\mathbf{p}} \sum_{\mathrm{t}} \mathrm{R}_{\mathrm{ipt}} \\
=\sum_{\mathrm{e}} \sum_{\mathrm{t}} \mathrm{d}_{\mathrm{iet}}
\end{gathered}
$$

$\mathrm{b}_{\mathrm{ipt}} \leq \mathrm{b}_{\mathrm{ipt}}^{\prime}$

$\forall \mathrm{i}, \mathrm{p}, \mathrm{t}$

Equations (6) and (7) are to show that the demand is satisfied. Thus, equation (6) ensures that all demand is met, and equation (7) shows the cost of unmet demand called lost sales.

$\sum_{\mathrm{c}} \sum_{\mathrm{p}} \sum_{\mathrm{t}} \mathrm{Q}_{\mathrm{cspt}} \geq \varepsilon_{\mathrm{s}}^{\mathrm{min}}$

$p q_{c s p t}^{\min } U C_{c s p t} \leq Q_{c s p t} \leq p q_{c s p t}^{\max } \cdot U C_{c s p t}$

$\forall c, s, p, t$

$A_{\text {iplt }} \leq u_{\text {ipt }}$

$\forall i, p, t, l$

$A_{i p l t}^{\prime} \leq u_{i p t}^{\prime}$

$\forall i, p, t, l$

$R_{i p t} \leq u_{i p t}^{\prime \prime}$

$\forall i, p, t$

$X_{c p t} \leq w_{c p t}$

$\forall c, p, t$

$X_{i p t}^{\prime} \leq w_{i p t}^{\prime}$

$\forall i, p, t$

$Y_{i w t} \leq k^{\prime}{ }_{i w t}$

$\forall \iota, w, t$
Equations (8) to (15) are the capacity constraints. Equation (8) shows the minimum supplier contribution constraint. Equation (9) restrict outsourcing capacity. Equations (10) and (11) limit production capacity in regular time and overtime production. Equation (12) restrict product outsourcing. Equations (13) and (14) show restrictions on the number of held materials and products in plants. Equation (15) shows restrictions on the number of products in warehouses.

$t q_{\text {ipet }}^{\text {min }} \cdot V_{\text {ipet }} \leq J_{\text {ipet }} \leq t q_{\text {ipet }}^{\max } \cdot V_{\text {ipet }}$ $\forall i, p, e, t$

$$
\begin{array}{r}
t q_{i p w t}^{\prime m i n} \cdot V^{\prime}{ }_{i p w t} \leq J_{i p w t}^{\prime} \leq t q_{i p w t}^{\prime m a x} \cdot V^{\prime}{ }_{i p w t} \\
\forall i, p, w, t \\
t q_{\text {iwet }}^{\prime m i n} \cdot V^{\prime \prime}{ }_{i w e t} \leq J_{\text {iwet }}^{\prime \prime} \leq t q_{i w e t}^{\prime m a x} \cdot V^{\prime \prime}{ }_{i w e t} \\
\forall i, w, e, t
\end{array}
$$

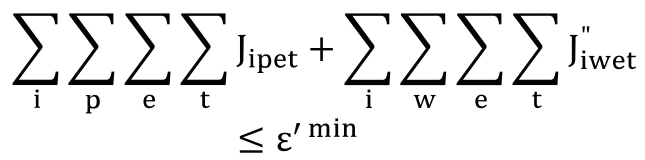

Equations (16) to (19) show restrictions on transportation. Equation (16) describes conditions upon transportation to end-users from plants. Equation (17) presents restrictions on transportation to warehouses from plants. Equation (18) reveals restrictions on transportation to end-users from warehouses. Equation (19) shows restrictions on transportation capacity.

$$
\frac{\sum_{c} \mathrm{nc}_{\mathrm{cmt}} \cdot \mathrm{tc}_{\mathrm{cmt}}}{\delta_{\mathrm{m}}} \leq \sum_{\mathrm{p}} \mathrm{tm}_{\mathrm{pmt}} \quad \forall m, t
$$




$$
\begin{array}{r}
\sum_{\mathrm{c}} \sum_{\mathrm{p}}\left(\mathrm{no}_{\mathrm{cim}} \cdot \mathrm{tc}_{\mathrm{cmpt}} / \delta_{\mathrm{m}}+\mathrm{s}_{\mathrm{cmt}}\right) \\
\quad \leq \mathrm{tm}_{\mathrm{pmt}} \\
\forall m, t, i, p
\end{array}
$$

$\sum_{\mathrm{i}} \sum_{\mathrm{p}} \sum_{\mathrm{l}} \mathrm{A}_{\mathrm{iplt}} \beta_{\mathrm{iplt}} \leq \sum_{\mathrm{p}} \sum_{\mathrm{l}} \mathrm{tl}_{\mathrm{plt}}$ $\forall \mathrm{t}$

$\sum_{\mathrm{i}} \sum_{\mathrm{p}} \sum_{\mathrm{l}} \mathrm{A}^{\prime}{ }_{\mathrm{iplt}} \beta_{\mathrm{iplt}} \leq \sum_{\mathrm{p}} \sum_{\mathrm{l}} \mathrm{tl}^{\prime}{ }_{\mathrm{plt}} \quad \forall \mathrm{t}$

$$
\begin{array}{ll}
\beta_{\text {iplt }} \leq \sum_{\mathrm{m}} \alpha_{\text {ipmlt }} & \forall i, p, l, t \\
\beta^{\prime}{ }_{\text {iplt }} \leq \sum_{\mathrm{m}} \alpha^{\prime}{ }_{\text {ipmlt }} & \forall i, p, l, t
\end{array}
$$

Equations (20) to (25) are constraints to show time limits. Equations (20) and (21) are total machine working time constraints. Equation (20) shows that the total time for all components to be processed in machines cannot exceed the total machine working time in each period considering the probability of each machine working correctly. In contrast, equation (21) represents that the total time needed for the units of component (used to make one unit of product) to be processed by machines, including the machine set-up time, cannot exceed the machine working time in each period. Equations (22) and (23) are total labor working time constraints, respectively, in regular time and overtime. Equations (24) and (25) imply the production time and labor working time limits, respectively. They show restrictions on production time correspondingly in regular time and overtime, which means total labor working time cannot exceed production time limits. Finally, all decision variables are non-negative.

We assume that the following parameters are known for this problem.

We know the area of plants and where they are located as well as the number of products that can be produced and stored in them. Also, the number of raw materials, components of each product that can be purchased from suppliers, as well as the fixed operating costs of plants are fixed. We also know the warehouses capacity and locations, and machine working time. Transportation plans and capacities are known. When a product is completed, it is either kept in the plant or sent to warehouses. The products can be directly delivered to end-users or be taken to warehouses according to the customers' needs.

\subsection{Solution methods}

In this paper, we used metaheuristic algorithms as they are found advantageous for solving multiobjective optimization problems. Each metaheuristic algorithm is characterized by many features, which the concept of some of them are in common. Many researchers [3] addressed the two essential concepts of metaheuristic algorithms, intensification (exploitation) and diversification (exploration). Thet defined these two concepts as follows: diversification is the ability to generate diverse solutions while searching the space on a global scale and refers to exploring the search space.

Furthermore, finding a proper balance between these two components is essential for an effective system to improve its performance. For example, if there is only too little exploration and too much exploitation, the system may face the local optima and not a global optimum. On the contrary, if too much exploration but too little exploitation, no convergence may occur the general search will be slowed down $[7 ; 19]$.

In the presented study, we have selected two solution approaches, NSGA-II and MOPSO. In this section, both solutions approach NSGA-II and MOP$\mathrm{SO}$ are presented in brief.

\subsubsection{NSGA-II algorithm}

NSGA-II algorithm suggested by Deb and colleagues [20] is a computationally elitist and swift multi-objective sophisticated algorithm based on a non-dominated sorting approach where setting sharing parameters is done efficiently. Also, it has been defined as a multi-objective optimization algorithm in which non-dominated solutions are identified and can represent different trade-offs between multiple objectives [20]. The difference between NSGA-II and GA is that the former uses an elitist principle that focuses on non-dominated solutions and selects individuals based on their non-dominated ranks and crowding distances.

As Nourbakhsh, et al. [21] mentioned in their work, it is considered one of the most efficient multiobjective evolutionary approaches in which a fast non-dominated sorting method is used and a crowding distance to rank and select the population fronts. Afterwards, the standard bimodal crossover and polynomial operators are applied to mix the current population with its offspring generated as the next generation. Eventually, the solutions are selected based on 
the best individuals in terms of non-dominance and diversity. For more details on the implementation of NSGA-II, refer to [20].

\subsubsection{MOPSO algorithm}

Coello and Lechuga [22] modified the original scheme of PSO and proposed MOPSO algorithms. Since then, MOPSO has been developed based on the Pareto optimality concept and has become one of the most active research areas in the field of multiobjective optimization. A number of variants of the origin multi-objective problems, the objectives can conflict with nature, which implies no unique solution for these problems. As an alternative, trade-off solutions are considered to represent the best possible solution. MOPSO was also presented by Moore [23]. In this proposed method, an external repository is used to store the information of non-dominated particles. Then, the leader is selected from the repository members to calculate the particle's velocity [24].

MOPSO algorithms are particularly developed to supply scalable and solid solutions. In addition, they strongly perform when there are less than three objective functions [25]. It has been used to a wide variety of optimization problems and has proven to produce very good results at a very low computational cost. This success has inspired researches to put much effort on MOPSOs [25]. For more details on the implementation of MOPSO, refer to [20].

\section{Computational results (output variables)}

In this section, two solution approaches are investigated. In the first part, the results of our mathematical model are provided for both solution methods, NSGA-II and MOPSO. In the second part, these two methods are compared in terms of five criteria. In the current section, the outcomes of the suggested mathematical model are presented. To solve the model, MATLAB software was devised. First, we compare both models (flexible vs inflexible) in terms of obtained optimal values for objective functions. Figs $2 \mathrm{a}$ and $2 \mathrm{~b}$ demonstrate the results obtained from the NSGA-II algorithm in terms of the first and second objective functions for both flexible and inflexible models. As shown in Figs 2a and 2b, the flexible model provides results that are superior to those of inflexible. It indicates a reduction of nearly $\% 22$ in costs (first objective function value) when the company is flexible enough in its production process. Similarly, values of the second objective function are reduced inflexible model by $\% 12.58$. The same results can be seen in Figs $3 a$ and 3 b, which show the results obtained from the MOPSO algorithm in terms of first and second objective functions. They imply that adopting a flexible approach results in fewer costs than the inflexible one. A reduction in costs by $\% 21.7$ and by 9.7 in product delivery time is obviously seen. Figs $4 \mathrm{a}$ and $4 \mathrm{~b}$ illustrate the final solutions of NSGA-II and MOPSO, respectively.

1st objective function values

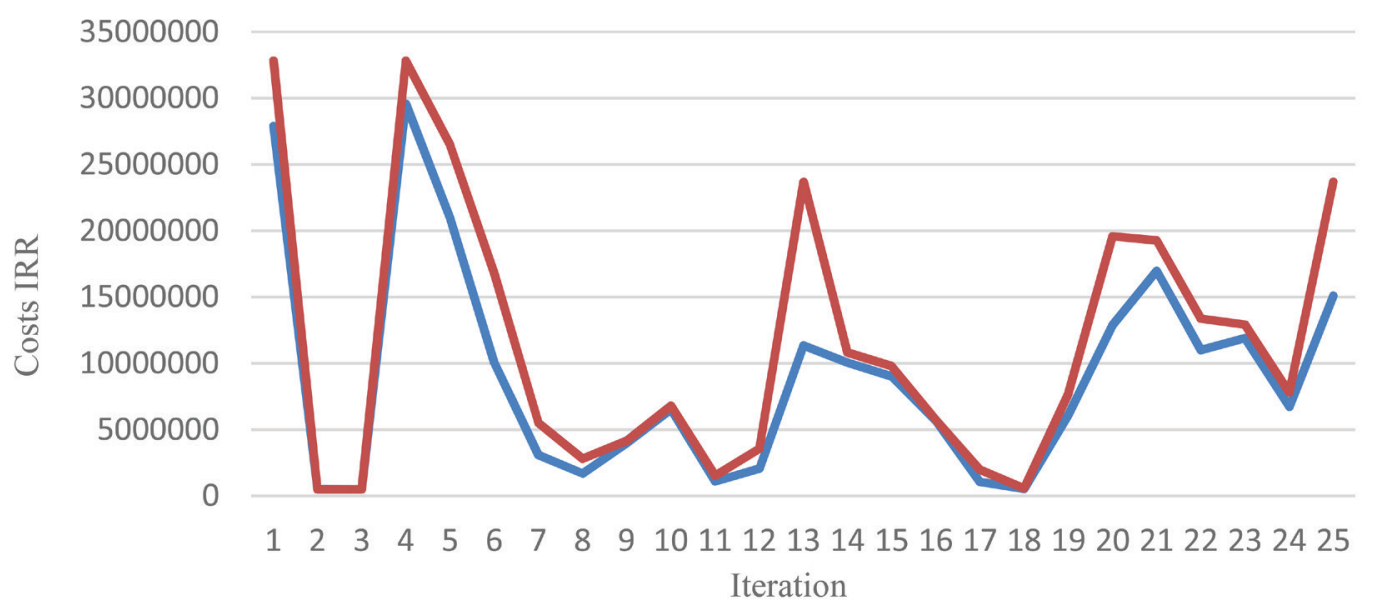

Objective function 1 flexible model $\longrightarrow$ Objective function 1 non_flexible model

Figure 2a. Comparison of 1st objective function values in flexible and inflexible models solved by NSGA-II 
2nd Objective function values

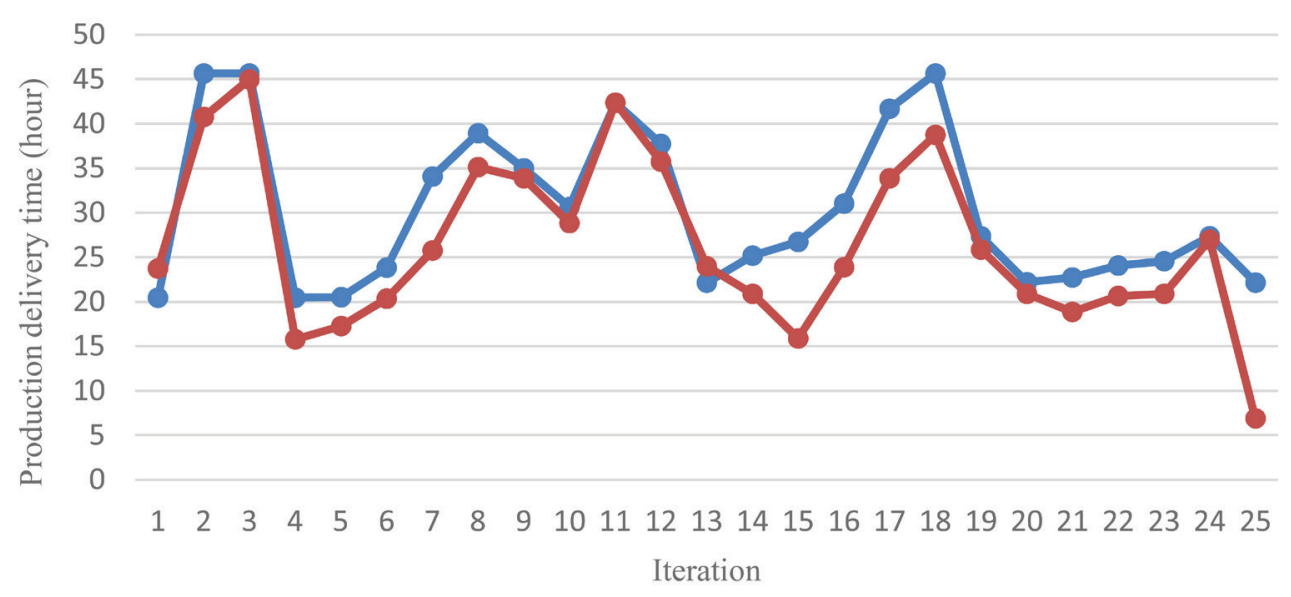

-Objective function 2 flexible model $\longrightarrow$ Objective function 2 non_flexible model

Figure $\mathbf{2 b}$. Comparison of 2nd objective function values in flexible and inflexible models solved by NSGA-II

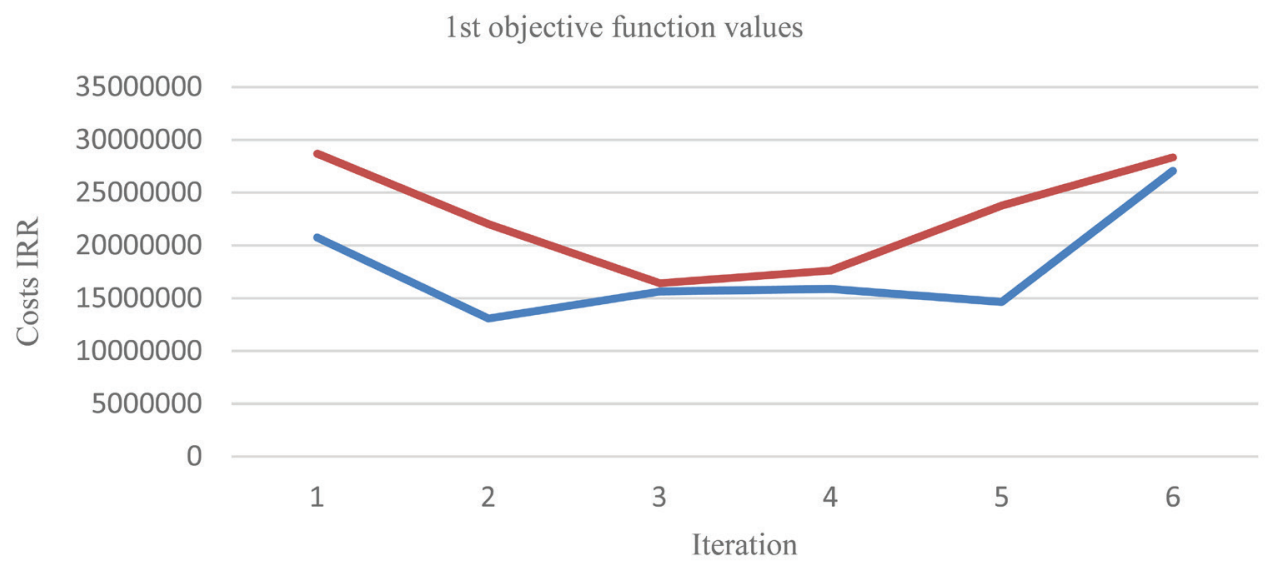

OBJECTIVE FUNCTION 1 flexible model

-OBJECTIVE FUNCTION 1 non_flexible model

Figure 3a. Comparison of 1st objective function values in flexible and inflexible models solved by MOPSO

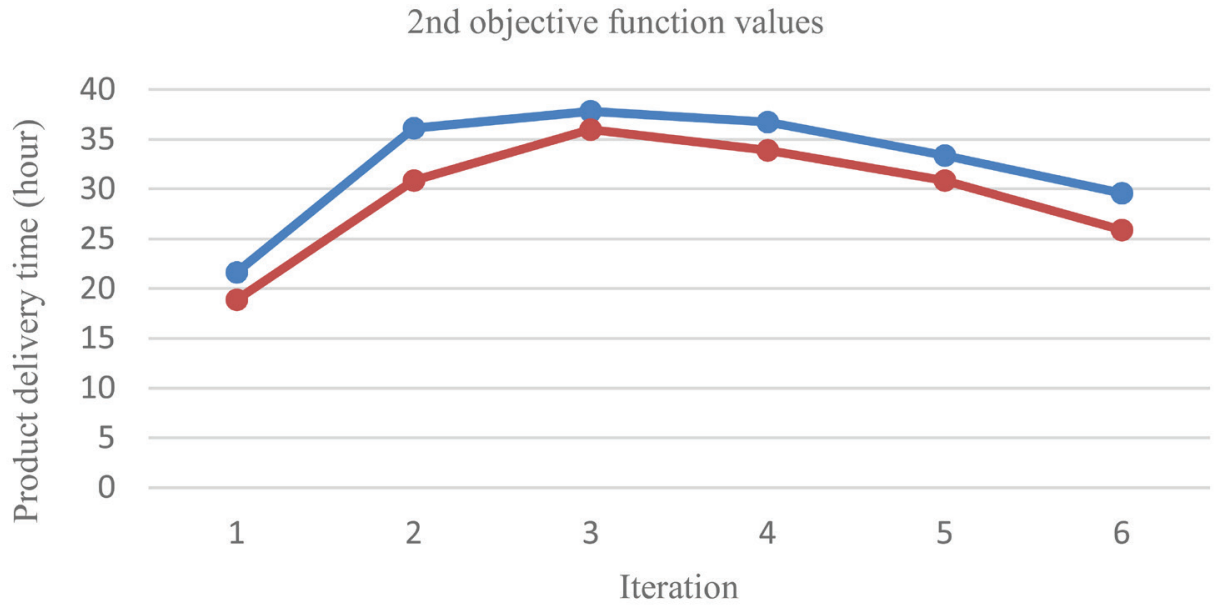

- OBJECTIVE FUNCTION 2 flexible model

-OBJECTIVE FUNCTION 2 inflexible model

Figure 3b. Comparison of 2nd objective function values in flexible and inflexible models solved by MOPSO 


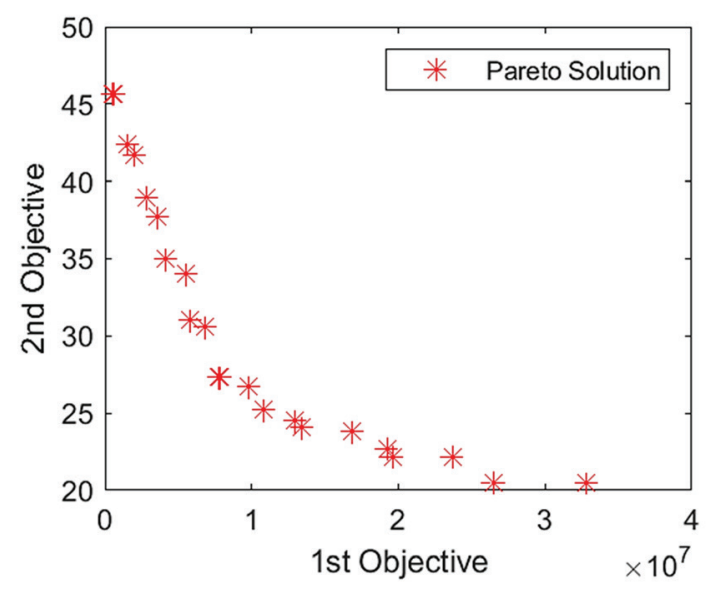

Final Solution- NSGAII

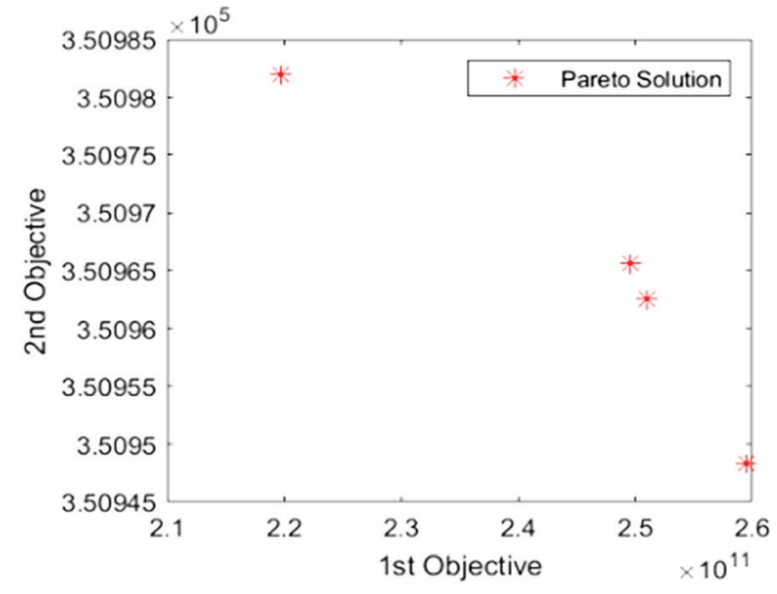

Initial Solution-NSGAII

Figure 4a. Final solution - NSGA-II

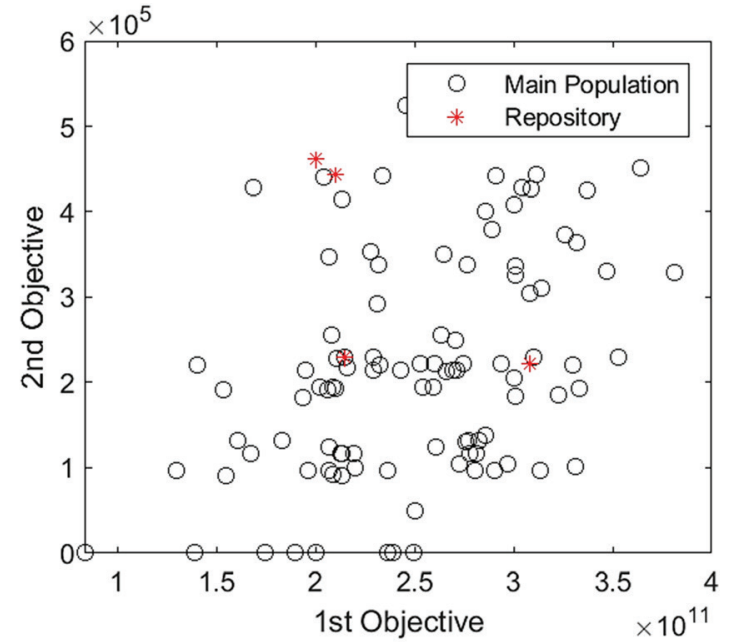

Initial Population \& Repository- MOPSO

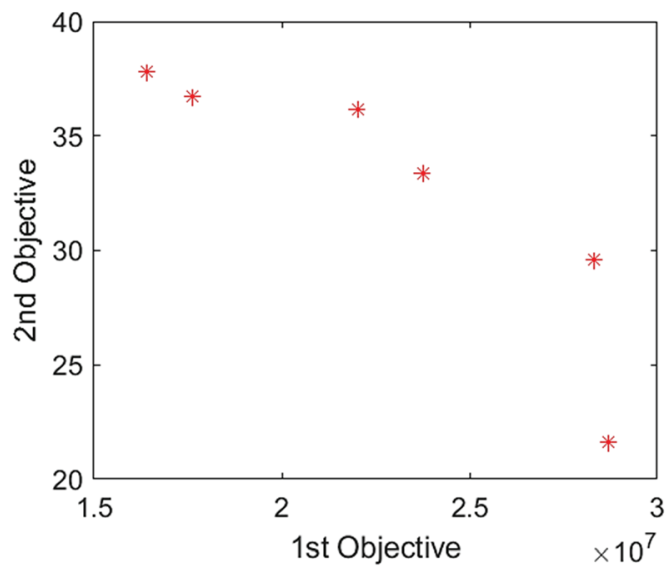

Final Solution MOPSO

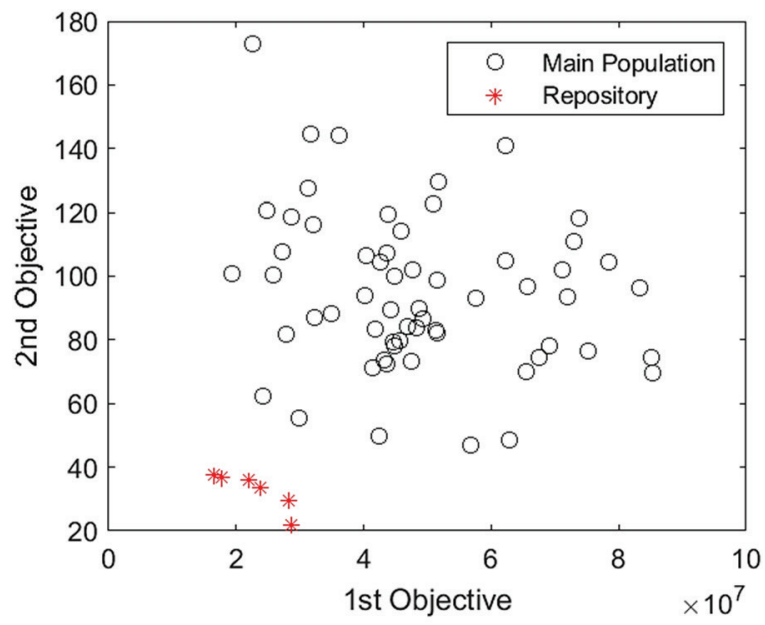

Final Solution MOPSO

(with Main Population)

Figure 4b. Final solution -MOPSO 
Table 5. Results from NSGA-II and MOPSO algorithms for both objective functions

\begin{tabular}{cccc}
\hline \multicolumn{2}{c}{ NSGA II } & \multicolumn{2}{c}{ MOPSO } \\
\hline First objective function & Second objective function & First objective function & Second objective function \\
\hline 32820035.48 & 20.48186868 & 28684130.16 & 21.64507728 \\
506045.671 & 45.6709938 & 22019327.09 & 36.13944236 \\
506045.671 & 45.6709938 & 16412269.93 & 37.8113903 \\
32820035.48 & 20.48186868 & 17626072.26 & 36.72651547 \\
26473595.49 & 20.49118306 & 23774340.78 & 33.38209212 \\
16816418.85 & 23.85264442 & 28331727.13 & 29.60270432 \\
\hline
\end{tabular}

The results of the model obtained from NSGA-II and MOPSO are expressed numerically in Table 5 .

The above results highlight a need to bridge the gap between the costs and flexibility dimensions. The way flexibility dimensions are defined and selected according to the unique circumstances of each case study is the key to success. However, it can be generalized from these results that adding flexibility dimensions is not always costly if appropriately chosen.

In order to help companies deal with uncertainty, these results provide them with a way to quickly and effectively overcome their rivals when it comes to being flexible. Another thing is that the overall results obtained from the two applied methods are different in each objective function. In order to compare the two algorithms, some indicators are defined in section 4.1 .

Many companies can alter this model according to their needs to perform better in terms of costs and meet their customers' needs.

The objective of this research is to provide mangers with some insights and workable solutions that fit the reality. The flexibility dimensions we add to the model are designed based on the needs of manufacturing plants in developing countries like Iran. Since local producers are under much pressure to compete with the international market to survive, they need to take immediate steps to defuse this crisis. They need to be flexible in production planning as well as setting long-term goals. The difficulty they might face is to clearly understand the extent to which they should apply flexibility dimensions. That's because there is an optimal point for applying each dimension in order to help them produce effectively. This paper caters for the small local businesses that are on the verge of collapse or the ones who want to develop their production line while boosting their profitability. This paper can lead them to outperform their larger rivals that as most of the companies' losses stem from redundancy costs.

\section{Discussions}

\subsection{Solution methods comparison}

Table 6 shows the results of the solution methods comparison.

In this part, two algorithms are used to solve the mathematical optimization model compared in terms of the following indicators according to (2015).

Spacing metric criterion: This criterion is calculated using equation (26), where is the mean of and shows the number of elements placed on the Pareto

Table 6. Results of the solution methods comparison

\begin{tabular}{ccccccccccc}
\hline Criterion & $\begin{array}{c}\text { Maximum spread } \\
\text { criterion }\end{array}$ & \multicolumn{2}{c}{$\begin{array}{c}\text { Spacing metrics } \\
\text { criterion }\end{array}$} & \multicolumn{2}{c}{$\begin{array}{c}\text { Number of Pareto } \\
\text { solutions criterion }\end{array}$} & $\begin{array}{c}\text { Mean ideal solution } \\
\text { criterion }\end{array}$ & \multicolumn{2}{c}{ Computational time criterion } \\
\hline & NSGA-II & MOPSO & NSGA-II & MOPSO & NSGA-II & MOPSO & NSGA-II & MOPSO & NSGA-II & MOPSO \\
1. & 3.23 & 1.23 & 2.9893 & 0.1067 & 25 & 6 & 1.17 & 1.28 & 721.7234211 & 618.686618 \\
2. & 3.87 & 1.47 & 1.9141 & 0.1121 & 21 & 10 & 9.26 & 1.99 & 1019.322898 & 970.032 \\
3. & 4.3 & 1.47 & 0.8631 & 0.1964 & 11 & 13 & 2.12 & 3.31 & 1623.877697 & 1392.044891 \\
4. & 4.2 & 1.59 & 2.1134 & 0.1836 & 19 & 11 & 2.82 & 5.71 & 2435.816546 & 2088.067336 \\
5. & 3.55 & 1.59 & 2.3922 & 0.1729 & 15 & 12 & 4.17 & 8.2 & 3653.724819 & 3132.101004 \\
\hline
\end{tabular}


frontier. The nearest neighborhood points are used to calculate di, and afterwards, $S$ is calculated. If the value of $\mathrm{S}$ is closer to zero, it means we have better solutions and spacing metrics.

$$
s=\sqrt{\frac{1}{|n-1|} \sum_{i=1}^{n}\left(d_{i}-\underline{d}\right)^{2}}
$$

Where

$\underline{d}=\sum_{i=1}^{n} \frac{d_{i}}{|n|}$ and $d_{i}=\min \sum_{m=1}^{2}\left|f_{m}^{1}-f_{m}^{k}\right|$

$k \in N, k \neq 1$

The Pareto solutions number: This standard implies the number of optimal solutions acquired by applying the multi-objective approach.

Computational time: time needed to calculate the results.

Mean ideal solution: This criterion shows the distance between Pareto fronts and the best value of the population.
Maximum spread: This criterion is the distance between two solutions which can be calculated using the following equation (27). The greater the values of maximum spread show a better solution.

$$
D=\sqrt{\sum_{j=1}^{n m}\left(\max f_{1}^{i}-\min f_{1}^{j}\right)^{2}}
$$

According to the above criteria, a comparison of two metaheuristic approaches is made in the following figures in detail. The computed results in Figure 5a show that for the maximum spread criterion, the NSGA-II technique overcomes the MOPSO algorithm and Figure 5b. for the spacing metric criterion. Furthermore, the NSGA-II algorithm provides us with superior results in nearly all situations based on the number of Pareto solutions, according to Figure $5 \mathrm{c}$. The mean ideal solution is shown in Figure 5d. while MOPSO needs less time to reach Pareto solutions, as is observed in Figure 5e.

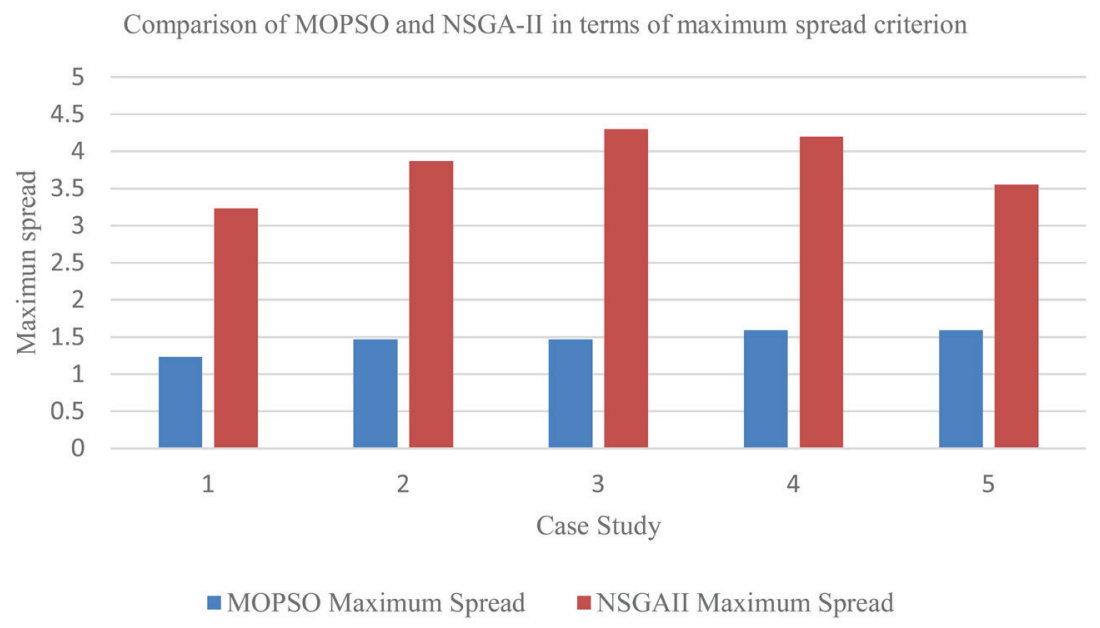

Figure 5a. Comparison of MOPSO and NSGA-II in terms of maximum spread criterion

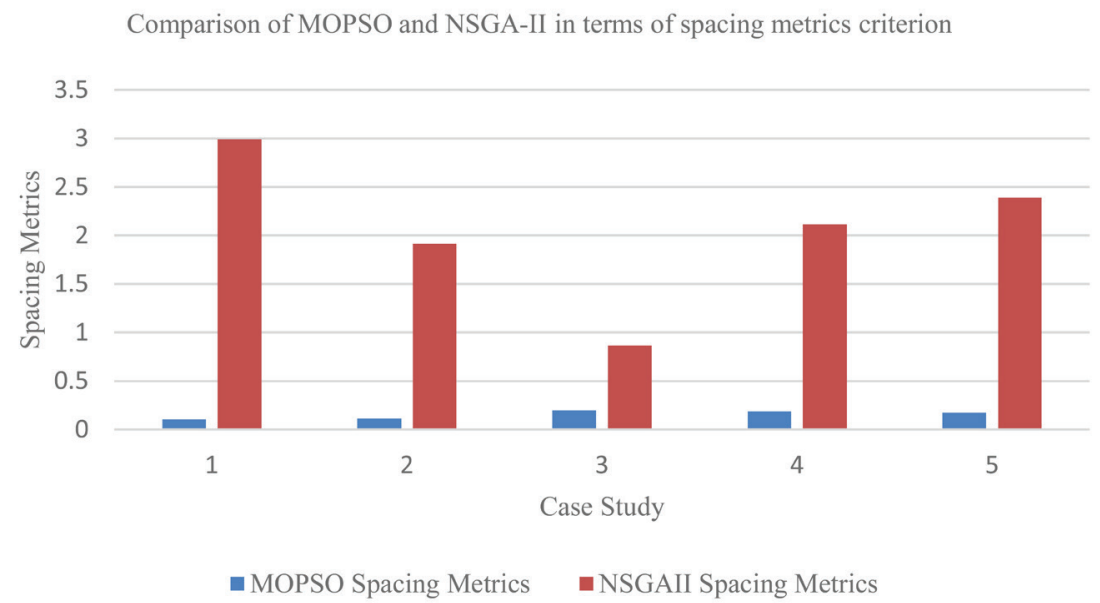

Figure $\mathbf{5 b}$. Comparison of MOPSO and NSGA-II in terms of spacing metrics criterion 
Comparison of MOPSO and NSGA-II in terms of number of Pareto solutions

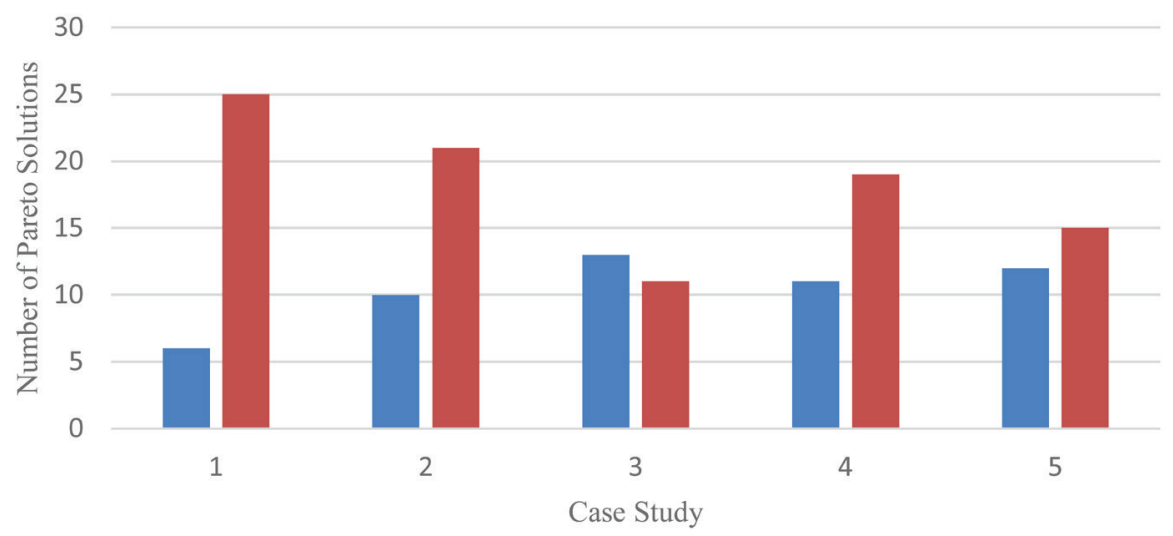

- MOPSO Number of Pareto Solutions a NSGAII Number of Pareto Solutions

Figure 5c. Comparison of MOPSO and NSGA-II in terms of number of Pareto solutions

Comparison of MOPSO and NSGA-II in terms of mean ideal solution

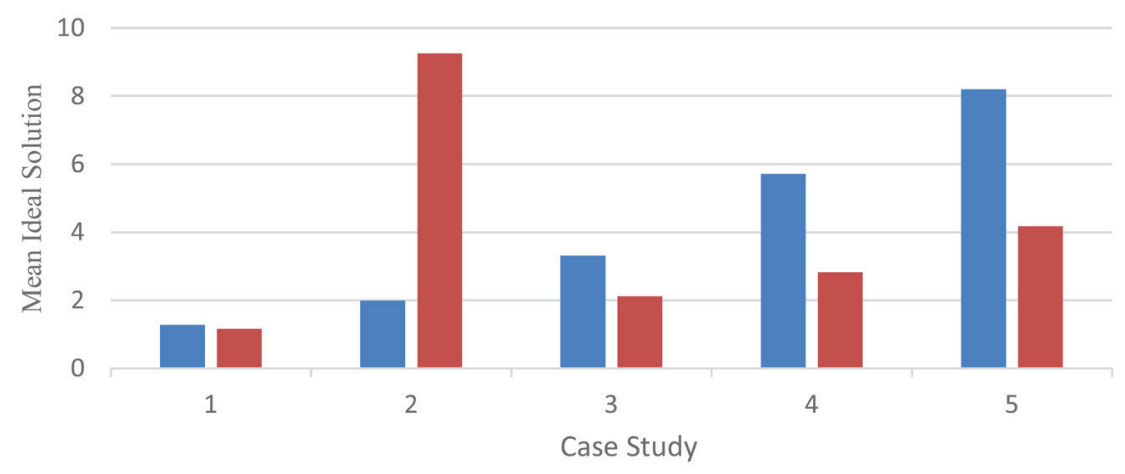

- MOPSO Mean Ideal Solution a NSGAII Mean Ideal Solution

Figure 5d. Comparison of MOPSO and NSGA-II in terms of mean ideal solution

\section{Comparison of MOPSO and NSGA-II in terms of computational time}

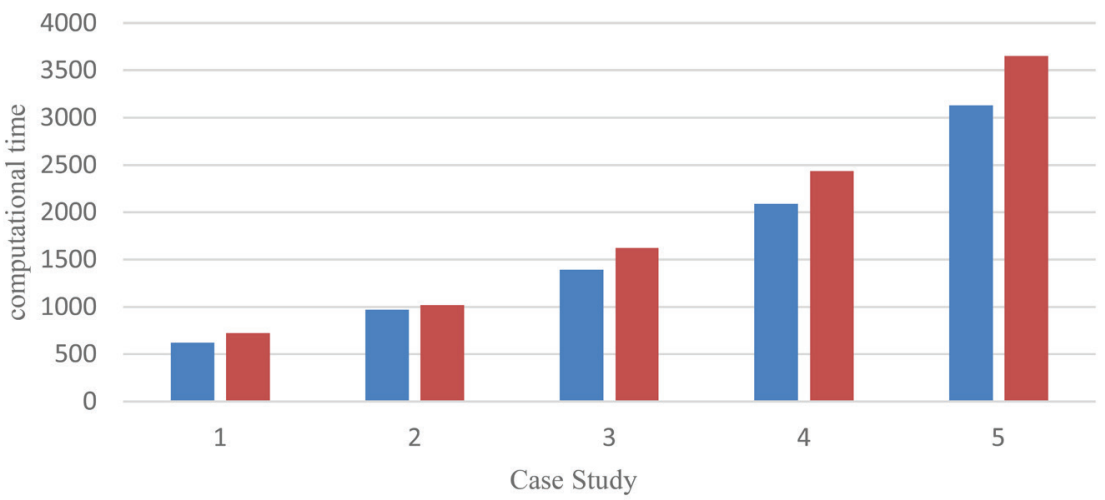

- MOPSO Comutational Time $\quad$ NSGAII Comutational Time

Figure 5e. Comparison of MOPSO and NSGA-II in terms of computational time 


\subsection{Sensitivity analysis of parameters}

Sensitivity analysis of two influential parameters of the offered model is presented in Figures 8a and $8 \mathrm{~b}$, whereas other parameters are considered constant. The consequences are not that unexpected; for greater values of lost sales cost of one unit of product in plant in time $\mathrm{t}$ shown in Figure 6a-outcomes in marked cost aggregation in the last attribute set. The same happens for the time required to produce one unit of a product by labor team I in plant in period t, illustrated in Figure 6b. In Figure 6b, the data are normalized.

\subsection{Parameter tuning using Taguchi method}

The Taguchi method is a quality design method suggested by Taguchi [26]. It mainly focuses on con-

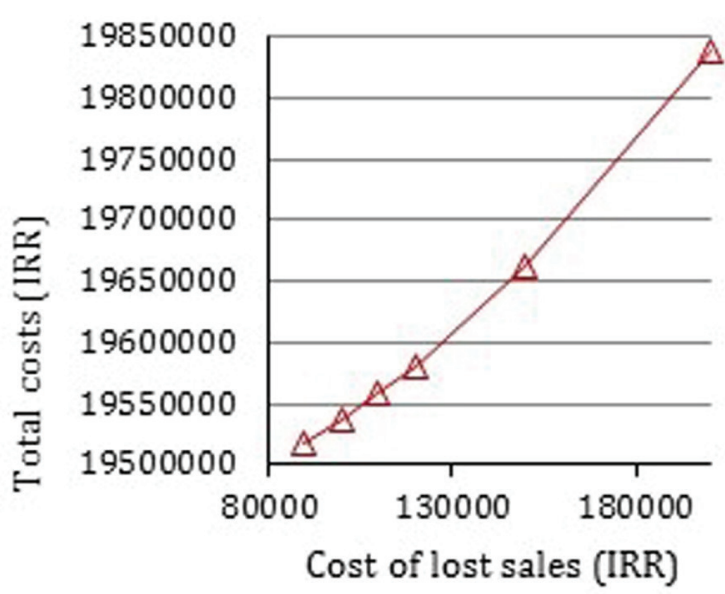

Figure 6a. Sensitivity analysis of the cost of lost sales of one unit of product $i$ duction experimental designs to find out the causes of variation in the production process while finding the ideal quality. Using this method leads to a reduction in experimental costs and producing highquality products. In this method, orthogonal arrays for experimental planning are used, and $\mathrm{La}$ (bc) is the symbol of each array, a represents the number of experiments, $\mathrm{b}$ is the level number, and $\mathrm{c}$ is the number of factors that can be placed. Consequently, an orthogonal array is chosen for experimental configuration. Tables 7 and 8 show the results of L27 (3_6) for NSGA-II and MOPSO. We use Minitab 19 to analyze the design using the Taguchi method. When the experiment configuration is done, and the experiment is performed, $\mathrm{C} 7$ is the experimental result, and the response charts for both NSGA-II and MOPSO are shown in Figures $7 \mathrm{a}$ and $7 \mathrm{~b}$ for NSGAII and MOPSO, respectively.

\section{Comparison of two objective functions}

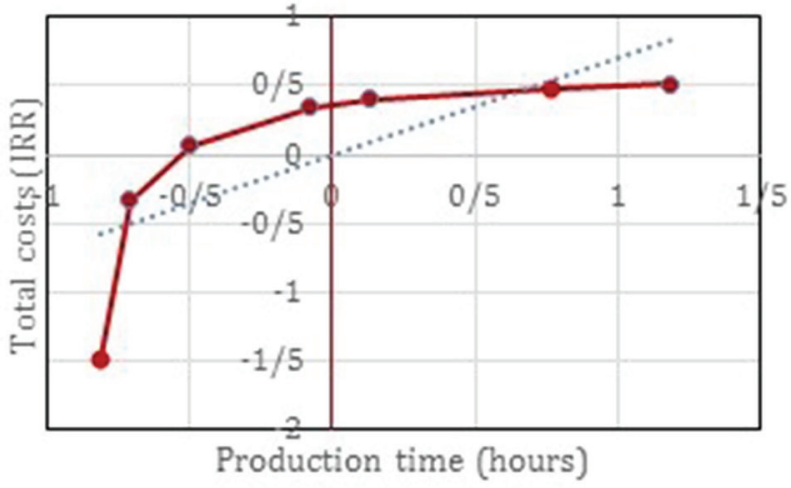

Figure $\mathbf{6 b}$. Sensitivity analysis of the time needed to make one unit of product

Table 7. Results from Taguchi method for NSGA-II

\begin{tabular}{lrrrrrr}
\hline Level & $\mathrm{A}$ & $\mathrm{B}$ & $\mathrm{C}$ & $\mathrm{D}$ & $\mathrm{E}$ & $\mathrm{F}$ \\
1 & 359.6 & 415.3 & 325.7 & 316.1 & 300.0 & 327.8 \\
2 & 297.2 & 267.6 & 317.4 & 340.6 & 315.1 & 322.5 \\
3 & 292.4 & 266.3 & 306.1 & 292.5 & 334.0 & 298.8 \\
Delta & 67.1 & 149.0 & 19.6 & 48.1 & 34.0 & 29.0 \\
Rank & 2 & 1 & 6 & 3 & 4 & 5 \\
\hline
\end{tabular}

Table 8. Results from Taguchi method for MOPSO

\begin{tabular}{lrrrrrr}
\hline Level & $\mathrm{A}$ & $\mathrm{B}$ & $\mathrm{C}$ & $\mathrm{D}$ & $\mathrm{E}$ & $\mathrm{F}$ \\
1 & 151.3 & 153.2 & 118.3 & 132.0 & 138.2 & 141.2 \\
2 & 151.0 & 109.8 & 158.5 & 139.9 & 131.3 & 154.7 \\
3 & 127.6 & 166.9 & 153.2 & 158.0 & 160.5 & 134.0 \\
Delta & 23.7 & 57.1 & 40.2 & 26.1 & 29.2 & 20.7 \\
Rank & 5 & 1 & 2 & 4 & 3 & 6 \\
\hline
\end{tabular}




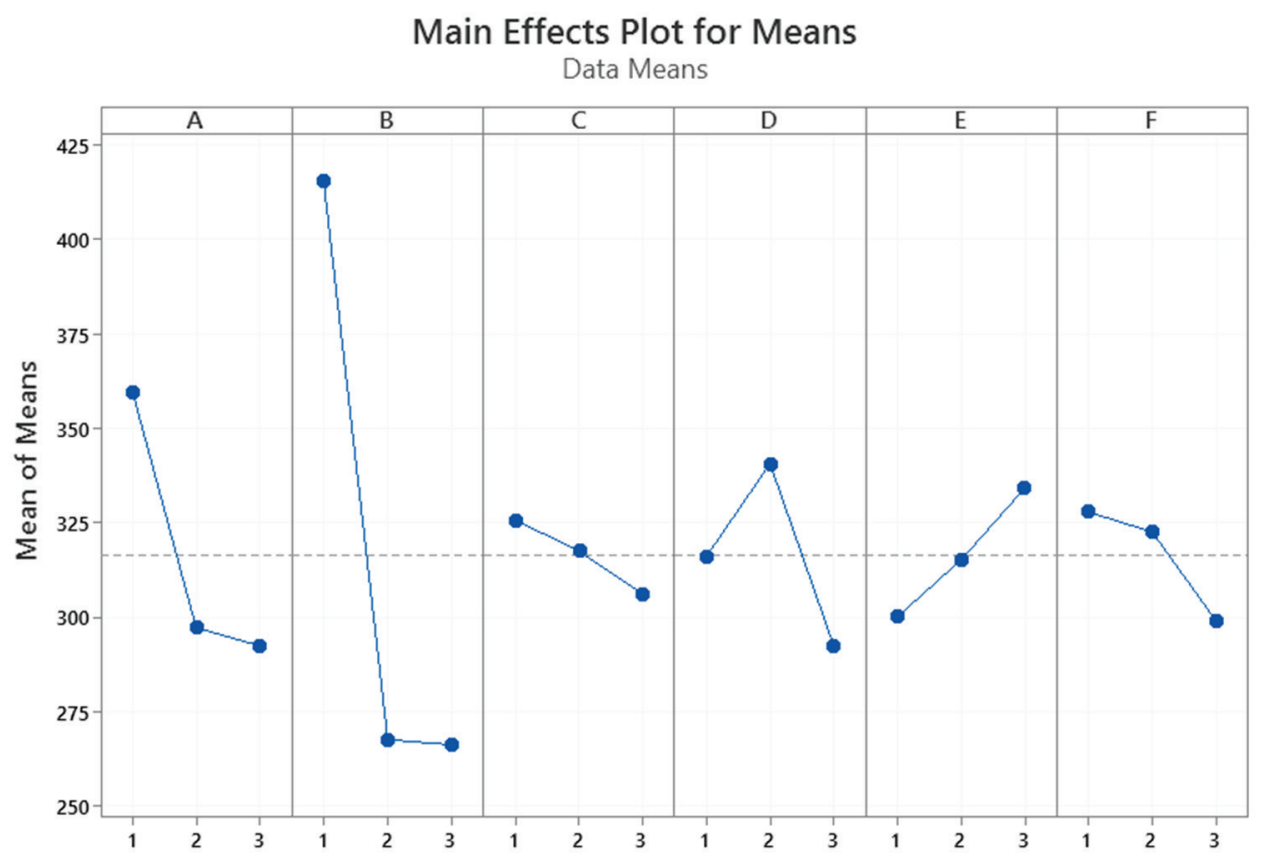

Figure 7a. Results from Taguchi method for NSGA-II

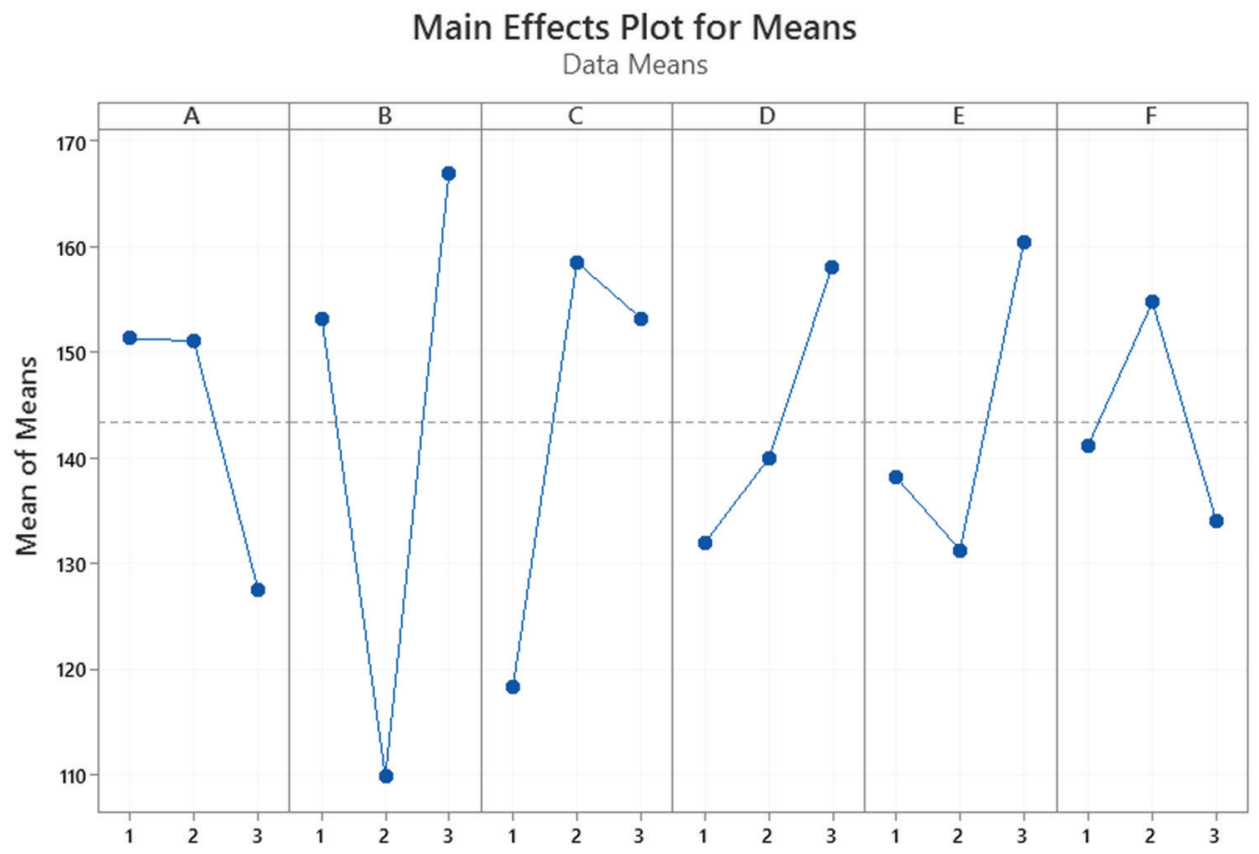

Figure 7b. Results from Taguchi method for MOPSO

\section{Conclusions}

The flexibility of the Supply chain has grown to be an essential topic of study for executives and academics. The present paper intended to examine the impact of considering the supply chain model's flexibility to enhance the system's performance. Hence, the primary contribution is to find a practical guide to incorporate flexibility dimensions into a supply chain management model. The pattern of supply chain flexibility, comprising production line flexibility, labor team flexibility, budget flexibility, and sourcing flexibility, has been produced to determine the most desirable situation between the inflexible and flexible models. A bi-objective model was proposed and resolved by applying NSGA-II and MOPSO algorithms to link flexibility and supply chain performance. The presented case study has been an automotive parts factory installed in the country Iran. Comparing the initial objective function rates in both 
applied solution methodologies, the requirement for flexibility in the production plant began. This design held less objective function values with whole flexibility dimensions, which reduced costs and product delivery time (PDT) in the company. Our results had significant implications for management. The subsequent achievement was that we discovered a link between PDT and the entire production cost. Since the products needed to be delivered at the right time to the customers, the company had to be flexible in PDT to avoid imposing substantial financial fines for delays. We also compared the two metaheuristic algorithms in terms of some criteria: spacing metric, computational time, the mean ideal solution, the Pareto solutions number, and maximum spread. The overall results show that NSGA2 performs better than MOPSO for a majority of criteria.

Throughout the study, we have incorporated some of the flexibility dimensions into the model; however, other flexibility dimensions can be combined with the presented model. More extra research is needed to increase further the knowledge of the value of different types of flexibility and the circumstances under which this flexibility is incorporated.

\section{Funding}

This research did not receive any specific grant from funding agencies in the public, commercial, or not-for-profit sectors.

\section{References}

[1] P. M. Swafford, S. Ghosh, and N. Murthy, "Achieving supply chain agility through IT integration and flexibility," International Journal of Production Economics, vol. 116, no. 2, pp. 288-297, 2008, doi: 10.1016/j.ijpe.2008.09.002.

[2] K. K.-L. Moon, C. Y. Yi, and E. Ngai, "An instrument for measuring supply chain flexibility for the textile and clothing companies," European Journal of Operational Research, vol. 222, no. 2, pp. 191-203, 2012, doi: 10.1016/j. ejor.2012.04.027

[3] M. Esmaeilikia, B. Fahimnia, J. Sarkis, K. Govindan, A. Kumar, and J. Mo, "Tactical supply chain planning models with inherent flexibility: definition and review," Annals of Operations Research, pp. 1-21, 2014, doi: 10.1007/s10479013-1513-2.

[4] S. Chiu, V. Chiu, M. Hwang, and Y. Chiu, "A delayed differentiation multiproduct model with the outsourcing of common parts, overtime strategy for end products, and quality reassurance," International Journal of Industrial Engineering Computations, vol. 12, no. 2, pp. 143-158, 2021, doi: 10.5267/j.ijiec.2021.1.001

[5] Y. Chiu, V. Chiu, Y. Wang, and M. Hwang, "A postponement model for multi-item replenishment decision considering overtime, commonality, and quality reassurance," International Journal of Industrial Engineering Computations, vol. 11, no. 4, pp. 509-524, 2020, doi: 10.5267/j.jijiec.2020.6.001.

[6] R. E. Giachetti, L. D. Martinez, O. A. Sáenz, and C.-S. Chen, "Analysis of the structural measures of flexibility and agility using a measurement theoretical framework," International journal of production economics, vol. 86, no. 1, pp. 47-62, 2003, doi: 10.1016/S0925-5273(03)00004-5.

[7] L. Krajewski, J. C. Wei, and L.-L. Tang, "Responding to schedule changes in build-to-order supply chains," Journal of Operations Management, vol. 23, no. 5, pp. 452-469, 2005, doi: 10.1016/j.jom.2004.10.006.

[8] L. K. Duclos, R. J. Vokurka, and R. R. Lummus, "A conceptual model of supply chain flexibility," Industrial Management \& Data Systems, vol. 103, no. 6, pp. 446-456, 2003, doi: 10.1108/02635570310480015.

[9] E. Korneeva, S. Hönigsberg, and F. T. Piller, "Mass Customization Capabilities in Practice - Introducing the Mass into Customized Tech-Textiles in an SME Network," Int. J. Ind. Eng. Manag., vol. 12, no. 2, pp. 115-128, 2021, doi: 10.24867/IJIEM-2021-2-281.

[10] M. K. Malhotra and A. W. Mackelprang, "Are internal manufacturing and external supply chain flexibilities complementary capabilities?," Journal of Operations Management, vol. 30, no. 3, pp. 180-200, 2012, doi: 10.1016/j.jom.2012.01.004.

[11] E. Mendonça Tachizawa and C. Giménez Thomsen, "Drivers and sources of supply flexibility: an exploratory study," International Journal of Operations \& Production Management, vol. 27, no. 10, pp. 1115-1136, 2007, doi: 10.1108/01443570710820657.

[12] S. K. Das and L. Abdel-Malek, "Modeling the flexibility of order quantities and lead-times in supply chains," International Journal of Production Economics, vol. 85, no. 2, pp. 171-181, 2003, doi: 10.1016/S0925-5273(03)00108-7

[13] C. Chandra and J. Grabis, "Role of flexibility in supply chain design and modeling-Introduction to the special issue," Omega, vol. 37, no. 4, pp. 743-745, 2009, doi: 10.1016/j. omega.2008.07.003

[14] U. Merschmann and U. W. Thonemann, "Supply chain flexibility, uncertainty and firm performance: an empirical analysis of German manufacturing firms," International Journal of Production Economics, vol. 130, no. 1, pp. 4353, 2011, doi: 10.1016/j.ijpe.2010.10.013.

[15] Z. Gong, "An economic evaluation model of supply chain flexibility," European Journal of Operational Research, vol. 184, no. 2, pp. 745-758, 2008, doi: 10.1016/j. ejor.2006.11.013.

[16] M. Zapp, C. Forster, A. Verl, and T. Bauernhansl, "A reference model for collaborative capacity planning between automotive and semiconductor industry," Procedia CIRP, vol. 3, pp. 155-160, 2012, doi: 10.1016/j.procir.2012.07.028.

[17] M. A. Panduro, C. A. Brizuela, J. Garza, S. Hinojosa, and A. Reyna, "A comparison of NSGA-II, DEMO, and EM-MOPSO for the multi-objective design of concentric rings antenna arrays," Journal of Electromagnetic Waves and Applications, vol. 27, no. 9, pp. 1100-1113, 2013, doi: 10.1080/09205071.2013.801040.

[18] R. Ojstersek, M. Brezocnik, and B. Buchmeister, "Multiobjective optimization of production scheduling with evolutionary computation: A review," International Journal of Industrial Engineering Computations, vol. 11, no. 3, pp. 359-376, 2020, doi: 10.5267/j.ijiec.2020.1.003

[19] R. K. Singh, P. Acharya, and S. Modgil, "A template-based approach to measure supply chain flexibility: a case study of Indian soap manufacturing firm," Measuring Business Excellence, vol. 24, no. 2, pp. 161-181, 2020, doi: 10.1108/ MBE-10-2018-0080 
[20] K. Deb, A. Pratap, S. Agarwal, and T. Meyarivan, "A fast and elitist multiobjective genetic algorithm: NSGA-II," IEEE transactions on evolutionary computation, vol. 6, no. 2, pp. 182-197, 2002, doi: 10.1109/4235.996017

[21] A. Nourbakhsh, H. Safikhani, and S. Derakhshan, "The comparison of multi-objective particle swarm optimization and NSGA II algorithm: applications in centrifugal pumps," Engineering Optimization, vol. 43, no. 10, pp. 1095-1113, 2011, doi: 10.1080/0305215X.2010.542811

[22] C. A. Coello Coello and M. S. Lechuga, "MOPSO: A proposal for multiple objective particle swarm optimization," in Proceedings of the 2002 Congress on Evolutionary Computation. CEC'02 (Cat. No. 02TH8600), 2002, vol. 2, pp. 1051-1056, doi: 10.1109/CEC.2002.1004388

[23] J. Moore and R. Chapman, "Application of particle swarm to multiobjective optimization," Department of Computer Science and Software Engineering. Auburn University, 1999.

[24] H. Monsef, M. Naghashzadegan, A. Jamali, and R. Farmani, "Comparison of evolutionary multi objective optimization algorithms in optimum design of water distribution network," Ain Shams Engineering Journal, vol. 10, no. 1, pp. 103-111, 2019, doi: 10.1016/j.asej.2018.04.003.

[25] A. Ghodratnama, F. Jolai, and R. Tavakkoli-Moghaddam, "Solving a new multi-objective multi-route flexible flow line problem by multi-objective particle swarm optimization and NSGA-II," Journal of Manufacturing Systems, vol. 36, pp. 189-202, 2015, doi: 10.1016/j.jmsy.2014.06.009

[26] G. Taguchi, System of experimental design: Engineering methods to optimize quality and minimize costs. Ann Arbor, Michigan, USA: UNIPUB/Kraus International Publications, 1987.

[27] N. P. Archer, V. Kumar, K. A. Fantazy, U. Kumar, and T. A. Boyle, "Implementation and management framework for supply chain flexibility," Journal of Enterprise Information Management, vol. 19, no. 3, pp. 303-319, 2006, doi: $10.1108 / 17410390610658487$

[28] X. Wu, X. Zhong, S. Song, and C. Wu, "Study on risk analysis of supply chain enterprises," Journal of Systems Engineering and Electronics, vol. 17, no. 4, pp. 781-787, 2006.

[29] M. Stevenson and M. Spring, "Flexibility from a supply chain perspective: definition and review," International Journal of Operations \& Production Management, vol. 27, no. 7, pp. 685-713, 2007, doi: 10.1108/01443570710756956.

[30] A. Gunasekaran, A. Reichhart, and M. Holweg, "Creating the customer-responsive supply chain: a reconciliation of concepts," International Journal of Operations \& Production Management, vol. 27, no. 11, pp. 1144-1172, 2007, doi: 10.1108/01443570710830575

[31] P. Kumar, R. Shankar, and S. S. Yadav, "Flexibility in global supply chain: modeling the enablers," Journal of Modelling in Management, vol. 3, no. 3, pp. 277-297, 2008, doi: 10.1108/17465660810920609

[32] G. P. Jenkins and D. S. Wright, "Managing inflexible supply chains," International Journal of Logistics Management, vol. 9, no. 2, pp. 83-90, 1998.

[33] A. E. Coronado M and A. C. Lyons, "Evaluating operations flexibility in industrial supply chains to support build-to-order initiatives," Business Process Management Journal, vol. 13, no. 4, pp. 572-587, 2007, doi: 10.1108/14637150710763586

[34] C. Y. Yi, E. Ngai, and K. Moon, "Supply chain flexibility in an uncertain environment: exploratory findings from five case studies," Supply Chain Management: An International Journal, vol. 16, no. 4, pp. 271-283, 2011, doi: $10.1108 / 13598541111139080$

[35] A. I. Malik and B. Sarkar, "Coordination supply chain management under flexible manufacturing, stochastic leadtime demand, and mixture of inventory," Mathematics, vol. 8, no. 6, p. 911, 2020, doi: 10.3390/math8060911

[36] M. Delic and D. R. Eyers, "The effect of additive manufacturing adoption on supply chain flexibility and performance: An empirical analysis from the automotive industry," International Journal of Production Economics, vol. 228, p. 107689, 2020, doi: 10.1016/j.ijpe.2020.107689

[37] A. Martínez Sánchez and M. Pérez Pérez, "Supply chain flexibility and firm performance: a conceptual model and empirical study in the automotive industry," International Journal of Operations \& Production Management, vol. 25, no. 7, pp. 681-700, 2005, doi: 10.1108/01443570510605090

[38] K. L. Choy, H. K. Chow, K. Tan, C.-K. Chan, E. C. Mok, and Q. Wang, "Leveraging the supply chain flexibility of third party logistics-Hybrid knowledge-based system approach," Expert Systems with Applications, vol. 35, no. 4, pp. 1998-2016, 2008, doi: 10.1016/j.eswa.2007.08.084

[39] N. Acur, C. Voss, M. Stevenson, and M. Spring, "Supply chain flexibility: an inter-firm empirical study," International Journal of Operations \& Production Management, vol. 29, no. 9, pp. 946-971, 2009, doi: 10.1108/01443570910986238

[40] S. Hua, S. Ranjan Chatterjee, and Y. Kang-kang, "Access flexibility, trust and performance in achieving competitiveness: An empirical study of Chinese suppliers and distributors,"Journal of Chinese Economic and Foreign Trade Studies, vol. 2, no. 1, pp. 31-46, 2009.

[41] J. Gosling, L. Purvis, and M. M. Naim, "Supply chain flexibility as a determinant of supplier selection," International Journal of Production Economics, vol. 128, no. 1, pp. 11-21, 2010, doi: 10.1016/j.ijpe.2009.08.029

[42] S.-J. Chuu, "Interactive group decision-making using a fuzzy linguistic approach for evaluating the flexibility in a supply chain," European Journal of Operational Research, vol. 213, no. 1, pp. 279-289, 2011, doi: 10.1080/21681015.2014.940070

[43] İ. Koçoğlu, S. Z. İmamoğlu, H. İnce, and H. Keskin, "The effect of supply chain integration on information sharing: Enhancing the supply chain performance," Procedia-Social and Behavioral Sciences, vol. 24, pp. 1630-1649, 2011, doi: 10.1016/j.sbspro.2011.09.016

[44] K.-H. Chang and H.-F. Huang, "Using influence strategies to advance supplier delivery flexibility: The moderating roles of trust and shared vision," Industrial Marketing Management, vol. 41, no. 5, pp. 849-860, 2012, doi: 10.1016/j.indmarman.2011.09.020

[45] C. Bai and J. Sarkis, "Flexibility in reverse logistics: a framework and evaluation approach," Journal of Cleaner Production, vol. 47, pp. 306-318, 2013, doi: 10.1016/j. jclepro.2013.01.005 